Fungal Genetic and Biology

2006, 43: 511-529

Doi: 10.1016/j.fgb.2006.02.006

\title{
Genetic characterization of the natural hybrid species Phytophthora alni as inferred from nuclear and mitochondrial DNA analyses
}

\author{
Renaud loos ${ }^{\mathrm{a}, \mathrm{b},{ }^{\star}}$, Axelle Andrieux ${ }^{\mathrm{a}}$, Benoît Marçais ${ }^{\mathrm{a}}$, Pascal Frey $^{\mathrm{a}}$ \\ a Institut National de la Recherche Agronomique, UMR1136, Pathologie Forestière, 54280 \\ Champenoux, France \\ ${ }^{b}$ Laboratoire National de la Protection des Végétaux, Unité de Mycologie Agricole et Forestière, \\ Domaine de Pixérécourt, 54220 Malzéville, France \\ *Corresponding author. Fax: +33 03833940 69. E-mail address: ioos@nancy.inra.fr (R. loos).
}

\section{Abstract}

The different subspecies of Phytophthora alni, P. alni subsp. alni (Paa), P. alni subsp. uniformis (Pau), and $P$. alni subsp. multiformis (Pam), are recent and widespread pathogens of alder in Europe. They are believed to be a group of emergent heteroploid hybrids between two phylogenetically close Phytophthora species. Nuclear and mitochondrial DNA analyses were performed, using a broad collection of $P$. alni and two closely related species, $P$. cambivora and $P$. fragariae. Paa possesses three different alleles for each of the nuclear genes we studied, two of which are present in Pam as well, whereas the third matches the single allele present in Pau. Moreover, Paa displays common mtDNA patterns with both Pam and Pau. A combination of the data suggests that Paa may have been generated on several occasions by hybridization between Pam and Pau, or their respective ancestors. Pau might have $P$. cambivora as a species ancestor, whereas Pam seems to have either been generated itself by an ancient reticulation or by autopolyploidization.

Keywords: RAS-Ypt; ASF-like; TRP1; GPA1; mtDNA-RFLP; cox1; nadh1; Interspecific hybridization

\section{Introduction}

The role of natural hybridization in the evolutionary history of many animal and plant species is well recognized today. Numerous examples illustrate that it has contributed also to the evolution of many pests and pathogens (Arnold, 2004). Until recently, only a few natural species hybrids were reported in the Fungi or Stramenipila kingdoms (Burnett, 1983). However, since the 1990s, there have been several reports of hybridization events among true fungi or oomycetes, especially involving plant pathogens (Olson and Stenlid, 2002). Man in't Veld et al. (1998) demonstrated that a new unknown Phytophthora pathogen active on Primula and Spathiphyllum in hydroponic culture systems was actually a hybrid between $P$. cactorum and P. nicotianae. Another recently described Phytophthora hybrid, highly aggressive on alder trees (Alnus spp.), is currently spreading in natural ecosystems across Europe (Gibbs et al., 2003). Gibbs (1995) previously described this alder Phytophthora as a taxon similar to $P$. cambivora, which is a common pathogen on hardwood trees. Brasier et al. (1999) then demonstrated that this pathogen was actually an interspecific hybrid. Based on morphological, serological, and genotypic traits, Brasier et al. (2004) formally described this 
new pathogen as Phytophthora alni. Because this new Phytophthora hybrid does not consist of a single entity but comprises a range of phenotypically diverse allopolyploid genotypes, $P$. alni was split into three subspecies: $P$. alni subsp. alni (Paa), $P$. alni subsp. uniformis (Pau), and P. alni subsp. multiformis (Pam) (Brasier et al., 2004).

In contrast with typical Phytophthora species, which are diploid organisms, Paa was shown to be near-tetraploid, consistent with possessing an allopolyploid genome (Brasier et al., 1999). Paa also displays an unusual internal transcribed spacer (ITS) polymorphism, i.e., numerous dimorphic sites within ITS sequences for a single isolate. On the other hand, the ploidy levels for the two other subspecies range from $2 n+2$ to $2 n+7$ for Pau and Pam, respectively. In contrast with Paa, nearly homogeneous ITS sequences were observed in both Pam and Pau: the ITS sequence for Pam differs from $P$. fragariae var. fragariae (Pff) or $P$. fragariae var. rubi (Pfr) by only a few bases, whereas the ITS sequence for Pau is very close to the $P$. cambivora (Pc) sequence (Brasier et al., 1999). According to chromosome karyotyping, ITS sequences, and amplified fragment length polymorphism (AFLP) fingerprinting, Brasier et al. (1999) hypothesized that $P$. cambivora was a parent of $P$. alni. On the other hand, recent isozyme analysis precludes the possibility that $P$. fragariae is involved sensu stricto in the hybridization process (Brasier, 2003; Nagy et al., 2003). Although $P$. alni was demonstrated to be a hybrid species, its origin remains unclear and additional data are required to trace back the ancestry to the parental species.

To address this problem, the use of molecular markers is particularly useful, and both nuclear and mitochondrial data may contribute to the understanding of the hybridization process. First, nuclear single-copy genes should be of particular interest for phylogeny purposes. In addition, the biparental inheritance and the absence of intergenomic concerted evolution in comparison to low copy or high copy nuclear genes make them particularly useful for studying the origin of hybrids and polyploidy lineages. Moreover, the use of genes containing introns, which are generally highly polymorphic regions, could potentially be of great interest for the discrimination of closely related Phytophthora species, such as the putative parents of $P$. alni (Brasier et al., 2004). Although the number of genes containing introns is much lower in Phytophthora sp. than in true Fungi (B. Tyler, personal communication), a few nuclear genes with introns have already been described for two Phytophthora species: P. parasitica (TRP1, Karlowsky and Prell, 1991) and P. infestans (RAS-Ypt; Chen and Roxby, 1996; GPA1, Laxalt et al., 2002). Besides, mitochondrial DNA analysis provides valuable information in the case of hybridization between two taxa; in the case of sexual mating for the Phytophthora genus, mitochondrial DNA is exclusively inherited from one of the parental lines (Whittaker et al., 1994).

In the present work, we studied the allelic distribution for orthologs of TRP1, RAS-Ypt, and GPA1 genes, along with another recently described single-copy gene containing one intron (ASF-like, Munakata et al., 2000). Mitochondrial DNA was studied through restriction pattern analysis and by the sequencing of two mitochondrial genes, cytochrome $\mathrm{c}$ oxidase subunit 1 (cox1) and NADH dehydrogenase subunit 1 (nadh1) (Kroon et al., 2004). This research, combining nuclear and mitochondrial data obtained from a large Europe-wide collection of Paa, Pam, Pau, Pc, Pff, and Pfr isolates, provides new insights into the hybrid status of $P$. alni.

\section{Materials and methods}

\subsection{Source and culture of Oomycete isolates for DNA extraction}

The Oomycete isolates used in this study are listed in Table 1. French isolates of $P$. alni or Phytophthora spp. were obtained by isolation from diseased plant material or biological baits carried out on soil sampled beneath the host, using the Phytophthoraselective PARBHY medium (Robin et al., 1998). Foreign isolates of $P$. alni and Phytophthora spp. were obtained from CBS (Centraalbureau voor Schimmelcultures, Utrecht, The 
Table 1. List of the isolates of Phytophthora spp. and Pythium spp. used in this study

\begin{tabular}{|c|c|c|c|c|c|c|}
\hline Species & Isolate & $\begin{array}{l}\text { Isolator/supplier, } \\
\text { reference }\end{array}$ & Host & Origin & $\begin{array}{l}\text { Year } \\
\text { isolated }\end{array}$ & $\begin{array}{l}\text { mtDNA } \\
\text { pattern }\end{array}$ \\
\hline \multirow{73}{*}{ P. alni subsp. alni } & PAA2 & J.C. Streito (2N0685) & Alnus glutinosa & France (Yrieu lake, Landes) & 2002 & M \\
\hline & PAA20 & J.C. Streito (71T1) & Alnus glutinosa & France (Oise river, Aisne) & 1997 & nd \\
\hline & PAA23 & J.C. Streito (82T1A) & Alnus glutinosa & France (Oise river, Aisne) & 1997 & M \\
\hline & PAA24 & J.C. Streito (84T2) & Alnus glutinosa & France (Nied river, Bas-Rhin) & 1997 & nd \\
\hline & PAA34 & J.C. Streito (98-7-5) & Alnus glutinosa & France (La Combauté river, Haute-Saône) & 1998 & M \\
\hline & PAA35 & J.C. Streito (98-7-6) & Alnus glutinosa & France (La Combauté river, Haute-Saône) & 1998 & nd \\
\hline & PAA38 & J.C. Streito (2N0529) & Alnus glutinosa & France (Aa river, Pas-de-Calais) & 2002 & M \\
\hline & PAA44 & J.C. Streito (DSFO98172) & Alnus glutinosa & France (Thouet river, Maine-et-Loire) & 1998 & nd \\
\hline & PAA47 & J.C. Streito (AUL026/1) & Alnus glutinosa & France (Moselle river, Vosges) & 1999 & $\mathrm{U}$ \\
\hline & PAA52 & J.C. Streito (9900783.4) & Alnus glutinosa & France (Meurthe river, Meurthe-et-Moselle) & 1999 & nd \\
\hline & PAA53 & J.C. Streito (1R0152) & Alnus glutinosa & France (Nied Française river, Moselle) & 2001 & M \\
\hline & PAA58 & J.C. Streito (1N0201) & Alnus glutinosa & France (Rhône river, Savoie) & 2001 & M \\
\hline & PAA100 & R. Ioos (Plbisa) & Alnus glutinosa & France (Semouse river, Haute-Saône) & 2003 & M \\
\hline & PAA102 & R. Ioos (P3d) & Alnus glutinosa & France (Semouse river, Haute-Saône) & 2003 & M \\
\hline & PAA107 & R. Ioos (Priva) & Alnus glutinosa & France (Semouse river, Haute-Saône) & 2003 & M \\
\hline & PAA111 & C. Husson (Ainvelle Sol) & Alnus glutinosa soil & France (Ainvelle forest, Haute-Saône) & 2003 & M \\
\hline & PAA1 12 & C. Husson (2ALD03) & Alnus glutinosa & France (Moine river, Maine-et-Loire) & 2003 & M \\
\hline & PAA113 & C. Husson (102-1) & Alnus glutinosa & France (Sarre river, Moselle) & 2003 & M \\
\hline & PAA114 & C. Husson (Moselle) & Alnus glutinosa & France (Moselle river, Vosges) & 2002 & M \\
\hline & PAA115 & C. Husson (370-2) & Alnus glutinosa & France (Sarre river, Moselle) & 2002 & M \\
\hline & PAA116 & R. Ioos (3N10094-5a) & Alnus glutinosa & France (Ognon river, Haute-Saône) & 2003 & M \\
\hline & PAA120 & R. Ioos (3N10048-3a) & Alnus glutinosa & France (Ognon river, Haute Saône) & 2003 & nd \\
\hline & PAA126 & C. Husson (Ainvelle4-4) & Alnus glutinosa & France (Semouse river, Haute-Saône) & 2003 & M \\
\hline & PAA129* & G. Capron (703) & Alnus glutinosa & France (Luy river, Landes) & 2003 & $\mathrm{U}$ \\
\hline & PAA $130^{*}$ & R. Ioos (1429-6b) & Alnus glutinosa & France (Saône river, Haute-Saône) & 2003 & M \\
\hline & PAA131 & C. Husson (Sol A15) & Alnus glutinosa soil & France (Ainvelle forest, Haute Saône) & 2003 & M \\
\hline & PAA133 & C. Husson (Sol A7) & Alnus glutinosa soil & France (Ainvelle forest, Haute Saône) & 2003 & nd \\
\hline & PAA147 & B. Thoirain (478-4) & Alnus glutinosa & France (Sarre river, Moselle) & 2004 & M \\
\hline & PAA149 & B. Thoirain (19BT) & Alnus glutinosa & France (Vezouze river, Meurthe et Moselle) & 2004 & $\mathrm{M}$ \\
\hline & PAA150 & B. Thoirain (10BT) & Alnus glutinosa & France (Vezouze river, Meurthe et Moselle) & 2004 & $\mathrm{M}$ \\
\hline & PAA $151^{*}$ & $\begin{array}{l}\text { B. Thoirain (2051000- } \\
\text { D12) }\end{array}$ & Alnus glutinosa & France (Moselle river, Vosges) & 2004 & $\mathrm{U}$ \\
\hline & PAA153 & $\begin{array}{l}\text { B. Thoirain (C2.1- } \\
\text { 2070250) }\end{array}$ & Alnus glutinosa & France (Meurthe river, Meurthe et Moselle) & 2004 & M \\
\hline & PAA160 & B. Thoirain (C9) & Alnus glutinosa & France (Mortagne river, Meurthe et Moselle) & 2004 & M \\
\hline & PAA161 & B. Thoirain (C18) & Alnus glutinosa & France (Chiers river, Meurthe et Moselle) & 2004 & M \\
\hline & PAA185 & R. Ioos (4N1605) & Alnus glutinosa & France (Ill river, Bas-Rhin) & 2004 & M \\
\hline & PAA195 & R. Ioos (Jouy2) & Alnus glutinosa & France (Eure river, Eure) & 2005 & M \\
\hline & PAA29 & J.C. Streito (9900715.6) & Alnus incana & Belgium (Train river, Brabant) & 1999 & nd \\
\hline & PAA86 & D. De Merlier $\left(2198^{\circ}\right)$ & Alnus glutinosa & Belgium (Salm river, Luxembourg) & 1999 & M \\
\hline & PAA88 & D. De Merlier $\left(2295^{\circ}\right)$ & Alnus glutinosa & Belgium (Lesse river, Luxembourg) & 2001 & M \\
\hline & PPA70 & $\begin{array}{l}\text { W. Man in’t Veld (PD } \\
\text { 20010933) }\end{array}$ & Alnus sp. & The Netherlands (Horst, Southern-Limburg) & Unknown & M \\
\hline & PAA74 & G. Mackaskill (P1275) & Alnus glutinosa & Great Britain (Scotland) & 2000 & $\mathrm{U}$ \\
\hline & PAA75 & J. Gibbs (P1272) & Alnus viridis & Great Britain (Scotland) & 2000 & M \\
\hline & PAA76 & J. Gibbs (P1271) & Alnus glutinosa & Great Britain (Scotland) & 2000 & M \\
\hline & PAA77 & J. Delcan (P1270) & Alnus glutinosa & Great Britain (Scotland) & 2000 & M \\
\hline & PAA78 & J. Delcan (P1960) & Alnus glutinosa & Great Britain (England) & 1997 & nd \\
\hline & PAA79 & J. Delcan (P957 $)$ & Alnus glutinosa & Great Britain (England) & 1997 & nd \\
\hline & PAA80 & J. Delcan (P950 $)$ & Alnus glutinosa & Great Britain (England) & 1997 & nd \\
\hline & PAA81 & J. Delcan (P937) & Alnus glutinosa & Great Britain (England) & 1997 & $\mathrm{U}$ \\
\hline & PAA82 & S. Gregory (P850) & Alnus glutinosa & Great Britain (England) & 1996 & M \\
\hline & PAA85 & C. Brasier $\left(\mathrm{P} 834^{\circ}\right)$ & Alnus glutinosa & Great Britain (England) & Unknown & M \\
\hline & PAA91 & Z. Nagy $\left(6^{d}\right)$ & Alnus glutinosa & Hungary (Hévíz) & 2001 & $M^{\prime}$ \\
\hline & PAA92 & Z. Nagy $\left(8^{d}\right)$ & Alnus glutinosa soil & Hungary (Hévíz) & 2001 & $\mathrm{M}^{\prime}$ \\
\hline & PAA93 & Z. Nagy $\left(9^{d}\right)$ & Alnus glutinosa soil & Hungary (Hévíz) & 2001 & $M^{\prime}$ \\
\hline & PAA94 & Z. Nagy $\left(1 a^{d}\right)$ & Alnus glutinosa soil & Hungary (Hévíz) & 2001 & $\mathbf{M}^{\prime}$ \\
\hline & PAA95 & Z. Nagy $\left(4-2^{d}\right)$ & Alnus glutinosa & Hungary (Hévíz) & 2001 & $\mathrm{M}^{\prime}$ \\
\hline & PAA134 & K. Kaminski (BBA 23/00) & Alnus glutinosa & Germany (Hessen) & 2000 & M \\
\hline & PAA1 $62^{*}$ & R. Ioos $(9 a)$ & Alnus glutinosa & Germany (Bavaria) & 2004 & $\mathrm{U}$ \\
\hline & PAA176 & R. Ioos (1c) & Alnus glutinosa & Germany (Bavaria) & 2004 & $\mathrm{U}$ \\
\hline & PAA141 & T. Cech (Pucking B10) & Alnus glutinosa & Austria (Donau Valley) & Unknown & $\mathrm{U}^{\prime}$ \\
\hline & PAA143* & L. Orlikowski (PO 192) & Alnus glutinosa & Poland (Pilicia river, Bialobrzegi) & 2002 & $\mathrm{M}^{\prime \prime}$ \\
\hline & PAA144 & L. Orlikowski (PO 193) & Alnus glutinosa & Poland (Vistula river, Koszyce) & 2003 & M" \\
\hline & PAA145 & L. Orlikowski (PO 203) & Alnus glutinosa & Poland (Pisia river, Radziejowice) & 2004 & $\mathrm{M}^{\prime \prime}$ \\
\hline & PAA146 & L. Orlikowski (PO 205) & Alnus glutinosa & Poland (Vistula river, Pulawy) & 2002 & $\mathrm{M}^{\prime \prime}$ \\
\hline & PAA178 & L. Orlikowski (PO318) & Alnus glutinosa & Poland (Notec river, Naklo) & 2003 & $\mathrm{M}^{\prime \prime}$ \\
\hline & PAA180 & L. Orlikowski (PO355) & Alnus glutinosa & Poland (Rudawka river, Morawica) & 2004 & $\mathrm{M}^{\prime \prime}$ \\
\hline & PAA181 & L. Orlikowski (PO379) & Alnus glutinosa & Poland (Bug river, Wlodawa) & 2004 & $\mathrm{M}^{\prime \prime}$ \\
\hline & PAA182 & L. Orlikowski (PO385) & Alnus glutinosa soil & Poland (Bug river, Wlodawa) & 2004 & $\mathrm{M}^{\prime \prime}$ \\
\hline & PAA183 & L. Orlikowski (PO399) & Alnus glutinosa soil & Poland (nursery, Siedliska) & 2004 & $\mathrm{M}^{\prime \prime}$ \\
\hline & PAA184 & L. Orlikowski (PO400) & Alnus glutinosa & Poland (nursery, Kornie) & 2004 & $\mathrm{M}^{\prime \prime}$ \\
\hline & PAA189 & L. Orlikowski (P. alni soil) & Alnus glutinosa soil & Poland (nursery, Siedliska) & 2004 & $\mathrm{M}^{\prime \prime}$ \\
\hline & PAA191 & $\begin{array}{l}\text { L. Orlikowski } \\
(121 \mathrm{AL} / \mathrm{KO} / 03)\end{array}$ & Alnus glutinosa & Poland (Vistula river, Koszyce) & 2004 & $\mathrm{M}^{\prime \prime}$ \\
\hline & PAA192 & $\begin{array}{l}\text { L. Orlikowski } \\
(106 \mathrm{AL} / \mathrm{PV})\end{array}$ & Alnus glutinosa & Poland (Bug river, Wlodawa) & 2004 & $\mathrm{M}^{\prime \prime}$ \\
\hline & PAA193 & $\begin{array}{l}\text { L. Orlikowski } \\
\text { (107/AL/B/03) }\end{array}$ & Alnus glutinosa & Poland (Bug river, Wlodawa) & 2004 & $\mathrm{M}^{\prime \prime}$ \\
\hline
\end{tabular}


Table 1, continued

\begin{tabular}{|c|c|c|c|c|c|c|}
\hline Species & Isolate & $\begin{array}{l}\text { Isolator/supplier, } \\
\text { reference }\end{array}$ & Host & Origin & $\begin{array}{l}\text { Year } \\
\text { isolated }\end{array}$ & $\begin{array}{l}\text { mtDNA } \\
\text { pattern }\end{array}$ \\
\hline \multirow{10}{*}{$\begin{array}{l}\text { P. alni subsp. } \\
\text { uniformis }\end{array}$} & PAU60* & J.C. Streito (AUL028) & Alnus glutinosa & France (Moselle river, Vosges) & 1999 & $\mathrm{U}^{\prime \prime}$ \\
\hline & PAU84* & C. Olsson (P875 $\left.5^{a, b, c, f}\right)$ & Alnus glutinosa & Sweden (Gothenburg) & 1997 & $\mathrm{U}^{\prime}$ \\
\hline & PAU87 & D. De Merlier $\left(2271^{\circ}\right)$ & Alnus glutinosa & Belgium (Amblève river, Liège) & 2001 & $\mathrm{U}$ \\
\hline & PAU187 & D. De Merlier $\left(2276^{\circ}\right)$ & Alnus glutinosa & Belgium (Canal du Centre, Hainaut) & 2001 & $\mathrm{U}$ \\
\hline & PAU188 & D. De Merlier $\left(2277^{\circ}\right)$ & Alnus incana & Belgium (Rulles river, luxembourg) & 2001 & $\mathrm{U}$ \\
\hline & PAU $89^{*}$ & P. Capretti (CBS109280 $)$ & Alnus cordata & Italy (Northern Tuscany) & 2000 & $\mathrm{U}$ \\
\hline & PAU96 & Z. Nagy $\left(155-\mathrm{a}^{\mathrm{d}}\right)$ & Alnus glutinosa & Hungary (Hanság) & 1999 & $\mathrm{U}$ \\
\hline & PAU97 & Z. Nagy $\left(155-b^{\mathrm{d}}\right)$ & Alnus glutinosa soil & Hungary (Hanság) & 1999 & $\mathrm{U}$ \\
\hline & PAU98 & Z. Nagy $\left(155-\mathrm{c}^{\mathrm{d}}\right)$ & Alnus glutinosa soil & Hungary (Hanság) & 1999 & $\mathrm{U}$ \\
\hline & PAU142 & A. Munda (Phy-A-Slo) & Alnus glutinosa & Slovenia (Lubljana) & 2003 & $\mathrm{U}$ \\
\hline \multirow{5}{*}{$\begin{array}{l}\text { P. alni subsp. } \\
\text { multiformis }\end{array}$} & PAM $54^{*}$ & J.C. Streito (DSFO/0125) & Alnus glutinosa & France (Aff river, Ille et Vilaine) & 2000 & M \\
\hline & PAM71 ${ }^{*}$ & W. Man in't Veld (W1139) & Alnus glutinosa soil & The Netherlands (De Wieden, Overijssel) & Unknown & M \\
\hline & PAM90 & $\begin{array}{l}\text { W. Man in't Veld } \\
(\text { P972a,c,f) }\end{array}$ & Alnus glutinosa soil & The Netherlands (De Wieden, Overijssel) & Unknown & M \\
\hline & PAM $73^{*}$ & S. Gregory (P841 $\left.1^{\mathrm{a}, \mathrm{c}, \mathrm{f}}\right)$ & Alnus glutinosa & Great Britain (England) & 1996 & M \\
\hline & PAM186 & D. De Merlier $\left(2274^{\circ}\right)$ & Alnus glutinosa & Belgium (Sambre river, Namur) & 2001 & $\mathrm{M}^{\prime}$ \\
\hline P. cambivora & PC463 & INRA Bordeaux & Castanea sativa & France (Lot et Garonne) & 1994 & $\mathrm{C} 2$ \\
\hline P. cambivora & $\mathrm{PC} 643^{*}$ & INRA Bordeaux & Castanea sativa soil & France (Aude) & 2000 & $\mathrm{Cl}$ \\
\hline P. cambivora & $\mathrm{PCJC} 17^{*}$ & C. Delatour & Quercus sp. soil & France (Haute Saône) & 1999 & $\mathrm{C} 2$ \\
\hline P. cambivora & PCGAl & C. Delatour & Quercus sp. soil & France (Haute Saône) & 1999 & $\mathrm{C} 2$ \\
\hline P. cambivora & PC99428 & R. Ioos & Castanea sativa & France & 1999 & $\mathrm{C} 2$ \\
\hline P. cambivora & PCST3R 1 & C. Delatour & Quercus petraea & France (Gironde) & 1999 & $\mathrm{C} 2$ \\
\hline P. cambivora & PC627 (oecde) & INRA Bordeaux & Castanea sativa & Italy & 2000 & $\mathrm{C} 2$ \\
\hline P. cambivora & PC1A21 & INRA Bordeaux & Quercus sp. soil & France (Vienne) & 1999 & $\mathrm{C} 2$ \\
\hline P. cambivora & $\mathrm{PC} 4 \mathrm{~N} 1425$ & LNPV-UMAF & Castanea sativa & France (Yvelines) & 2004 & $\mathrm{C} 2$ \\
\hline P. cambivora & PC4N444 & LNPV-UMAF & Castanea sativa & France (Eure) & 2004 & $\mathrm{C} 2$ \\
\hline $\begin{array}{l}\text { P. fragariae var. } \\
\text { fragariae }\end{array}$ & PFF1 & K. Hughes & Fragaria $x$ ananassa & Unknown & Unknown & nd \\
\hline $\begin{array}{l}\text { P. fragariae var. } \\
\text { fragariae }\end{array}$ & PFF209.46 & CBS (CBS209.46) & Fragaria $x$ ananassa & Great Britain (England) & 1946 & $\mathrm{FF}$ \\
\hline $\begin{array}{l}\text { P. fragariae var. } \\
\text { fragariae }\end{array}$ & PFF309* & CBS (CBS 309.62) & Fragaria $x$ ananassa & Great Britain (Scotland) & 1962 & FF \\
\hline $\begin{array}{l}\text { P. fragariae var. } \\
\text { rubi }\end{array}$ & PFRVR 59 & D. Cooke (FVR 59) & Rubus sp. & Great Britain & Unknown & FR \\
\hline $\begin{array}{l}\text { P. fragariae var. } \\
\text { rubi }\end{array}$ & PFR163-2 & A. Baudry (163-2) & Rubus sp. & France & Unknown & FR \\
\hline $\begin{array}{l}\text { P. fragariae var. } \\
\text { rubi }\end{array}$ & PFR2 & K. Hughes & Rubus sp. & Great Britain & Unknown & FR \\
\hline $\begin{array}{l}\text { P. fragariae var. } \\
\text { rubi }\end{array}$ & PFR967.95 & CBS (CBS967.95) & Rubus sp. & Great Britain (Scotland) & 1985 & FR \\
\hline $\begin{array}{l}\text { P. fragariae var. } \\
\text { rubi }\end{array}$ & PFR $109^{*}$ & CBS (CBS109.892) & Rubus sp. & Great Britain (Scotland) & 1991 & FR \\
\hline P. cactorum & CAC4810/TJ & C. Delatour & Unknown & France & Unknown & \\
\hline P. cinnamomi & DSFO2N0964 & J.C. Streito & Castanea sativa & France & 2002 & \\
\hline P. cinnamomi & DSFA970060 & J.C. Streito & Quercus suber & France & 1997 & \\
\hline P. cinnamomi & DSFO990050 & J.C. Streito & Castanea sativa soil & France & 1999 & \\
\hline P. cinnamomi & P382 & C. Brasier & $\begin{array}{l}\text { Nothofagus procera } \\
\text { soil }\end{array}$ & Great Britain & 1980 & \\
\hline P. citricola & 2N0750-171 & J.C. Streito & Unknown & France & 2002 & \\
\hline P. citricola & AUL 045 AP7 & J.C. Streito & Alnus glutinosa & France & 1999 & \\
\hline P. citricola & 2AE5 & C. Delatour & Quercus sp. soil & France & 1998 & \\
\hline P. citricola & $3 \mathrm{~N} 1345-17$ & R. Ioos & Alnus glutinosa & France & 2003 & \\
\hline P. citrophthora & 2N1021 & J.C. Streito & Rosa sp. & France & 2002 & \\
\hline P. cryptogea & 990675 & J.C. Streito & Actinidia sinensis & France & 1999 & \\
\hline P. erythroseptica & 960713 & J.C. Streito & Polygonum oberti & France & 1999 & \\
\hline P. europaea & AL5 & C. Delatour & Quercus sp. soil & France & 1998 & \\
\hline P. europaea & 2AU2 & C. Delatour & Quercus sp. soil & France & 1999 & \\
\hline P. gonapodyides & Gonap 4 & C. Delatour & Quercus sp. soil & France & 1998 & \\
\hline P. gonapodyides & AB4 & C. Delatour & Quercus sp. soil & France & 1998 & \\
\hline P. humicola & $3 \mathrm{~N} 1245-\mathrm{j}$ & R. Ioos & Alnus glutinosa soil & France & 2003 & \\
\hline P. ilicis & $3 \mathrm{~N} 1245-1$ & R. Ioos & Alnus glutinosa soil & France & 2003 & \\
\hline P. inundata & 9500802 & J.C. Streito & Alnus glutinosa soil & France & 1998 & \\
\hline P. lateralis & 98093.1-SPV & J.C. Streito & Chamaecyparis sp. & France & 1998 & \\
\hline P. megasperma & 3N1245-m & R. Ioos & Alnus glutinosa soil & France & 2003 & \\
\hline P. megasperma & BK1 & C. Delatour & Quercus sp. soil & France & 1998 & \\
\hline P. megasperma & 03-12 & C. Delatour & $\begin{array}{l}\text { water under } \\
\text { Quercus sp. }\end{array}$ & France & 1998 & \\
\hline P. megasperma & mega 1 & T. Jung & Unknown & Germany & 1998 & \\
\hline P. megasperma & 8RPOC3 & C. Delatour & Quercus sp. soil & France & 1998 & \\
\hline P. nicotianae & 960579 & J.C. Streito & Nicotiana tabacum & France & 1996 & \\
\hline P. taxon forestsoil & 8CARPPOC1 & C. Delatour & Quercus sp. soil & France & 1998 & \\
\hline P. palmivora & 970423 & J.C. Streito & Hedera sp. & France & 1997 & \\
\hline P. parasitica & 970029 & J.C. Streito & $\begin{array}{l}\text { Lycopersicon } \\
\text { esculentum }\end{array}$ & France & 1997 & \\
\hline
\end{tabular}


Table 1, continued

\begin{tabular}{|c|c|c|c|c|c|c|}
\hline Species & Isolate & $\begin{array}{l}\text { Isolator/supplier, } \\
\text { reference }\end{array}$ & Host & Origin & $\begin{array}{l}\text { Year } \\
\text { isolated }\end{array}$ & $\begin{array}{l}\text { mtDNA } \\
\text { pattern }\end{array}$ \\
\hline $\begin{array}{l}\text { P. taxon } \\
\text { Pgchlamydo }\end{array}$ & Haye,3,1 & C. Delatour & Quercus sp. soil & France & 1998 & \\
\hline P. pseudosyringae & EW5 & C. Delatour & Quercus sp. soil & France & 1998 & \\
\hline P. psychrophila & FF20 & C. Delatour & Quercus sp. soil & France & 1998 & \\
\hline P. quercina & FNA & C. Delatour & Quercus sp. soil & France & 1999 & \\
\hline P. quercina & Mers2 & C. Delatour & Quercus sp. soil & France & 1999 & \\
\hline P. ramorum & 2N0983 & C. Saurat & Rhododendron sp. & France & 2002 & \\
\hline P. ramorum & $3 \mathrm{~N} 0003$ & C. Saurat & Viburnum sp. & France & 2002 & \\
\hline P. sojae & 443 & F. Panabières & Glycine $\max$ & Unknown & Unknc & \\
\hline P. syringae & $2 \mathrm{JZ} 2$ & C. Delatour & Quercus sp. soil & France & 1999 & \\
\hline $\begin{array}{l}\text { Pythium } \\
\quad \text { aphanidermatum }\end{array}$ & Ctsa & R. Ioos & Unknown & France & 2003 & \\
\hline $\begin{array}{l}\text { Pythium } \\
\text { sylvaticum }\end{array}$ & $0675 / \mathrm{a}$ & R. Ioos & Unknown & France & 2003 & \\
\hline $\begin{array}{l}\text { Pythium } \\
\quad \text { intermedium }\end{array}$ & $02 / 84 / 1$ & S. Verger & Unknown & France & Unknown & \\
\hline $\begin{array}{l}\text { Pythium } \\
\quad \text { irregulare }\end{array}$ & $02 / 57 / 1$ & S. Verger & Unknown & France & Unknown & \\
\hline Pythium ultimum & $433 / 3$ & S. Verger & Unknown & France & Unknown & \\
\hline Pythium sp. & $3 \mathrm{~N} 1345-11$ & R. Ioos & Alnus glutinosa soil & France & 2003 & \\
\hline
\end{tabular}

The different mitochondrial DNA patterns resolved in this study are indicated.

$n d$, not determined.

a Also studied by Delcan and Brasier (2001).

b Also studied by Brasier et al. (1999).

c Also studied by De Merlier et al. (2005).

d Also studied by Nagy et al. (2003).

e Also studied by Santini et al. (2003).

${ }^{f}$ Also studied by Brasier and Kirk (2001).

* Isolate used for sequencing in this study.

Table 2. List of the degenerate primers designed in this study

\begin{tabular}{|c|c|c|c|c|c|c|}
\hline Gene & $\begin{array}{l}\text { Original reference } \\
\text { (GenBank Accession No.) }\end{array}$ & Additional sequences $^{\mathrm{a}}$ & $\begin{array}{l}\text { Primer } \\
\text { (forward/reverse) }\end{array}$ & Sequence $\left(5^{\prime}-3^{\prime}\right)$ & Size $^{b}$ & Intron $(\mathrm{s})^{\mathrm{c}}$ \\
\hline$A S F$-like & Homo sapiens (AB028628) & $\begin{array}{l}\text { P. sojae } \\
\text { (Scaffold_6 1068853-1069936) } \\
\text { P. ramorum } \\
\text { (Scaffold_43 348071-349019) }\end{array}$ & $\begin{array}{l}\text { ASF-E1-1F } \\
\text { ASF-E2-2R }\end{array}$ & $\begin{array}{l}\text { ACCAACATCACCGTGCTGGAC } \\
\text { CGTTGTTGACGTAGTAGCCCAC }\end{array}$ & $388-402$ & 1 \\
\hline$G P A 1$ & $\begin{array}{l}\text { P. infestans (AY050536), } \\
\text { P. palmivora (AY050537) }\end{array}$ & $\begin{array}{l}\text { P. sojae } \\
\text { (Scaffold_34 298473-301143) } \\
\text { P. ramorum } \\
\text { (Scaffold_59 316212-318351) }\end{array}$ & $\begin{array}{l}\text { GPA-E1-1F } \\
\text { GPA-E2-1R }\end{array}$ & $\begin{array}{l}\text { GGACTCTGTGCGTCCCAGATG } \\
\text { ATAATTGGTGTGCAGTGCCGC }\end{array}$ & $286-312$ & 1 \\
\hline$R A S-Y p t$ & P. infestans (U30474) & $\begin{array}{l}\text { P. cinnamomi (AF454368) } \\
\text { P. cryptogea (AF454367) } \\
\text { P. citricola (AF454369) } \\
\text { P. sojae } \\
\text { (Scaffold_30 367461-369077) } \\
\text { P. ramorum } \\
\text { (Scaffold_16 280386-282150) }\end{array}$ & $\begin{array}{l}\text { RAS-E1-1F } \\
\text { RAS-E5-1R }\end{array}$ & $\begin{array}{l}\text { ATGAACCCCGAATAGTRCGTGC } \\
\text { TGTTSACGTTCTCRCAGGCG }\end{array}$ & $666-698$ & 4 \\
\hline$T R P 1$ & P. parasitica (M64473) & $\begin{array}{l}\text { P. sojae } \\
\text { (Scaffold_25 46183-57099) } \\
\text { P. ramorum } \\
\text { (Scaffold_52 330699-333530) }\end{array}$ & $\begin{array}{l}\text { TRP-E1-1F } \\
\text { TRP-E3-1R }\end{array}$ & $\begin{array}{l}\text { GAGGAGATCGCGGCGCAGCG } \\
\text { GCGCACATRCCGAGVTTGTG }\end{array}$ & $661-765$ & 2 \\
\hline
\end{tabular}

${ }^{a}$ Refer to GenBank accession number for other species or localization of the respective similar sequence in the $P$. sojae and the $P$. ramorum JGI sequencing projects.

${ }^{\mathrm{b}}$ Range of amplicon length yielded in silico using the designed primer pair with all available sequences.

${ }^{\mathrm{c}}$ Number of introns that are located within the ampli $\mathrm{W}$ ed region using the designed primers.

Netherlands) or from several European colleagues. Assignment of the isolates to one of the three subspecies of $P$. alni was achieved by combining the examination of the morphological features of each isolate in pure culture according to Brasier et al. (2004), and analyzing restriction patterns of the ITS region using a series of enzymes, according to Brasier et al. (1999) and Cooke et al. (2000). The assignment was further confirmed using subspecific SCAR-based PCR primers (loos et al., 2005). 
A panel of 15 isolates was selected from among Paa, Pau, Pam, P. cambivora, and $P$. fragariae and used for cloning and sequencing: five isolates of $P$. alni subsp. alni (PAA129, PAA130, PAA143, PAA151, and PAA162), three isolates of $P$. alni subsp. uniformis (PAU60, PAU84, and PAU89), three isolates of $P$. alni subsp. multiformis (PAM54, PAM71, and PAM73), two isolates of P. cambivora (PC643 and PCJC17), one isolate of $P$. fragariae var. fragariae (PFF309), and one isolate of $P$. fragariae var. rubi (PFR109), chosen from different geographical locations.

All the isolates were grown shaking in $6 \mathrm{ml}$ of liquid V8 juice medium (Miller, 1955). After incubation at $22^{\circ} \mathrm{C}$ for 4-7 days, the mycelium was harvested by filtration on a sterile Whatman $\mathrm{N}^{\circ} 1$ paper (Maidstone, England) and stored in this condition at $i^{2} 0^{\circ} \mathrm{C}$ until DNA extraction. DNA was extracted using commercial plant DNA extraction kits (DNeasy plant mini kit ${ }^{\circledR}$, Qiagen, Courtaboeuf, France) and as previously described (loos et al., 2005).

\subsection{RFLP of mitochondrial DNA}

Total DNA was extracted using commercial plant DNA extraction kits (DNeasy plant mini $\mathrm{kit}^{\mathrm{Q}}$ ) as previously described (loos et al., 2005), except that the quantity of dried mycelium was increased from 200 to $600 \mathrm{mg}$, and $10 \mathrm{I}$ of proteinase $\mathrm{K}(20 \mathrm{mg} / \mathrm{ml})$ was added to the lysis buffer. Incubation time with the lysis buffer was also increased to $20 \mathrm{~min}$. Four to 8 $\mathrm{g}$ of total DNA was typically recovered. Mitochondrial DNA is present in multiple copies and can be separated from genomic DNA by digestion with restriction enzymes, which cut regions rich in $\mathrm{G}+\mathrm{C}$ (Spitzer et al., 1989). Accordingly, 20 I of total DNA were digested twice for $12 \mathrm{~h}$ with each time flve units of Haelll or Hpall and mtDNA patterns were resolved after a $15 \mathrm{~h}$ electrophoresis $(0.6 \mathrm{~V} / \mathrm{cm})$ on a $0.8 \%$ agarose gel in TBE $0.5 £$ buffer. Gels were stained with ethidium bromide and images were recorded with a CCD camera and a GELDOC $2000^{\circledR}$ gel documentation system (Biorad, Marne-La-Coquette, France).

\subsection{Design of nuclear gene-specific degenerate primers}

For each of the four nuclear genes studied, namely ASF-like, GPA1, RAS-Ypt, and TRP1, the original sequence deposited in GenBank was retrieved and used as a basis for similarity research in other Phytophthora DNA resources (see accession numbers in Table 2). Nucleotide similarities were searched for in the GenBank database, and the P. ramorum and the $P$. sojae assembled sequences recently released in the public domain (http://genome.jgi-psf.org/), using the BLASTn algorithm and the Phytophthora Functional Genomics Database, which gathers sequences from $P$. infestans and $P$. sojae, and using the PFGD search filter (http://www.pfgd.org/pfgd/filter.html).

For each gene, all the available orthologous sequences from different Phytophthora species were then aligned using ClustalW (Thompson et al., 1994) and a series of degenerate primer pairs were manually designed in highly conserved regions located in exons. The location of the primers was chosen in order to enable PCR amplification of the largest part of the gene, including as many intronic regions as possible. The primer pairs that best amplified the target region in all species of the 15-isolate panel were retained and used for cloning. Table 2 lists the respective forward and reverse PCR primers chosen for each of the four nuclear genes.

\subsection{Amplification and cloning of the nuclear and the mitochondrial genes}

Each of the four nuclear genes was amplified by PCR for each of the 15 isolates of the panel. Amplification of the four nuclear genes was carried out in a 20- $\mu \mathrm{l}$ mixture containing $1 \times$ Taq polymerase buffer (Sigma-Aldrich, L'Isle d'Abeau, France), $1.8 \mathrm{mM} \mathrm{MgCl} 2(1.5 \mathrm{mM}$ for TRP1), $0.7 \mathrm{~g} / \mu \mathrm{l}$ bovine serum albumin (Sigma), $0.45 \mu \mathrm{M}(0.2 \mu \mathrm{M}$ for TRP1) of each forward and reverse gene-specific primer, $180 \mathrm{mM}$ dNTPs, $0.6 \mathrm{U}$ of Taq DNA Polymerase (Sigma-Aldrich), $2 \mu \mathrm{l}$ of template DNA (30-80 ng), and molecular biology grade water was added to $20 \mu \mathrm{l}$. The cycling profile for PCR included an initial denaturation step at $95^{\circ} \mathrm{C}$ for 3 min, followed by 35 cycles of denaturation for $30 \mathrm{~s}$ at $94^{\circ} \mathrm{C}$, annealing for $30 \mathrm{~s}$ at $62^{\circ} \mathrm{C}\left(58^{\circ} \mathrm{C}\right.$ for RAS-Ypt), and elongation for $1 \mathrm{~min}$ at $72^{\circ} \mathrm{C}$, and a final extension step at $72^{\circ} \mathrm{C}$ for $7 \mathrm{~min}$. 
Amplification of the two mitochondrial genes, nadh1 and cox1, was performed for a limited panel of six isolates: Paa (PAA129 and PAA130), Pam (PAM54), Pau (PAU60), and Pc (PCJC17 and PC643). PCRs were carried out with the mitochondrial gene-specific primers designed by Kroon et al. (2004) using the same parameters as described above for the nuclear genes with slight modifications. The annealing temperatures were lowered to 58 and $53{ }^{\circ} \mathrm{C}$ for nadh1 and cox1 amplifications, respectively, and the concentration of $\mathrm{MgCl}_{2}$ was raised to $3.5 \mathrm{mM}$ for cox1, as suggested by Kroon et al. (2004).

Each of the gene-specific PCR products was cloned for each isolate of the panel, using a TOPO ${ }^{\circledR}$-TA cloning kit (Invitrogen, Cergy Pontoise, France) and following the manufacturer's instructions.

Table 3. GenBank accession numbers of the sequences obtained for the six genes cloned in this study for the 15-isolate panel

\begin{tabular}{|c|c|c|c|c|c|c|c|}
\hline \multirow[t]{2}{*}{ Species } & \multirow[t]{2}{*}{ Isolate } & \multicolumn{4}{|c|}{ Nuclear genes } & \multicolumn{2}{|c|}{ Mitochondrial genes } \\
\hline & & $A S F$-like & $G P A 1$ & $R A S-Y p t$ & $T R P 1$ & $\cos 1$ & nadh 1 \\
\hline \multirow[t]{15}{*}{ P. alni subsp. alni } & \multirow[t]{3}{*}{ PAA 129} & DQ092818 & DQ179047 & DQ093974 & DQ093997 & \multirow[t]{3}{*}{ DQ202499 } & DQ202488 \\
\hline & & DQ092819 & DQ179048 & DQ179054 & DQ093998 & & DQ202489 \\
\hline & & DQ092820 & DQ179049 & & & & \\
\hline & \multirow[t]{3}{*}{ PAA 130} & DQ092821 & DQ179050 & DQ093975 & DQ202482 & \multirow[t]{12}{*}{ DQ202500 } & DQ202490 \\
\hline & & DQ092822 & DQ179051 & DQ093976 & DQ202483 & & DQ202491 \\
\hline & & DQ092823 & & DQ093977 & DQ212060 & & \\
\hline & \multirow[t]{3}{*}{ PAA 143} & |DQ092824 & DQ092851 & DQ093978 & DQ093999 & & \\
\hline & & DQ092825 & DQ179052 & DQ093979 & DQ094000 & & \\
\hline & & DQ092831 & & DQ093980 & & & \\
\hline & \multirow[t]{3}{*}{ PAA 151} & DQ092826 & DQ092852 & DQ093981 & DQ094001 & & \\
\hline & & DQ092827 & DQ092853 & DQ093982 & DQ094002 & & \\
\hline & & & DQ092854 & & & & \\
\hline & \multirow[t]{3}{*}{ PAA 162} & DQ092828 & DQ092855 & DQ093983 & DQ094003 & & \\
\hline & & DQ092829 & DQ092856 & DQ093984 & DQ094004 & & \\
\hline & & DQ092830 & & & & & \\
\hline \multirow[t]{7}{*}{ P. alni subsp. uniformis } & \multirow[t]{3}{*}{ PAU 60} & DQ092811 & DQ092857 & DQ093971 & DQ202480 & \multirow[t]{7}{*}{ DQ202498 } & DQ202486 \\
\hline & & DQ092812 & & & & & DQ202487 \\
\hline & & DQ092813 & & & & & \\
\hline & \multirow[t]{3}{*}{ PAU 84} & DQ092814 & DQ092849 & DQ093972 & DQ093996 & & \\
\hline & & DQ092815 & & & & & \\
\hline & & DQ092816 & & & & & \\
\hline & PAU 89 & DQ092817 & DQ092850 & DQ093973 & DQ202481 & & \\
\hline \multirow[t]{7}{*}{ P. alni subsp. multiformis } & \multirow[t]{2}{*}{ PAM 54} & DQ092806 & DQ092843 & DQ093966 & DQ093991 & \multirow{7}{*}{$\begin{array}{l}\text { DQ202496 } \\
\text { DQ202497 }\end{array}$} & DQ202484 \\
\hline & & DQ092807 & DQ092844 & DQ179053 & DQ093992 & & DQ202485 \\
\hline & \multirow{3}{*}{ PAM 71} & DQ092808 & DQ092845 & DQ093967 & DQ093993 & & \\
\hline & & DQ179044 & DQ179046 & DQ093968 & DQ202479 & & \\
\hline & & DQ179045 & & & & & \\
\hline & \multirow[t]{2}{*}{ PAM 73} & DQ092809 & DQ092847 & DQ093969 & DQ093994 & & \\
\hline & & DQ092810 & DQ092848 & DQ093970 & DQ093995 & & \\
\hline \multirow[t]{9}{*}{ P. cambivora } & \multirow[t]{5}{*}{ PC643 } & DQ092834 & DQ092861 & DQ093987 & \multirow[t]{5}{*}{ DQ094007 } & DQ202502 & DQ202494 \\
\hline & & DQ092835 & DQ092862 & DQ093988 & & DQ202503 & DQ202495 \\
\hline & & DQ092836 & & & & & \\
\hline & & DQ092837 & & & & & \\
\hline & & DQ092838 & & & & & \\
\hline & PCJC17 & DQ092839 & DQ092860 & DQ093989 & DQ094008, & DQ202501 & DQ202492 \\
\hline & & DQ092840 & & DQ093990 & DQ094009 & & DQ202493 \\
\hline & & DQ092841 & & & & & \\
\hline & & DQ092842 & & & & & \\
\hline P. fragariae var. fragariae & PFF309 & DQ092832 & DQ092858 & DQ093985 & DQ094005 & & \\
\hline P. fragariae var. rubi & PFR109 & DQ092833 & DQ092859 & DQ093986 & DQ094006 & & \\
\hline
\end{tabular}

\subsection{Selection of the clones and sequencing}

For each isolate, hundreds of positive clones were typically recovered for each of the cloned genes. For each isolate $x$ gene combination, 10 positive clones were randomly selected and tested by heteroduplex analysis in order to detect sequence polymorphisms among the 10 inserts, following a protocol adapted from Pinar et al. (1997). Heteroduplex analysis is a conformational technique that makes it possible to detect mutations in PCR- 
amplified products. The migration of heteroduplex DNA in agarose gel electrophoresis is different from that of homoduplex DNA because of an altered tri-dimensional structure. Brie $X$ $y$, for each group of 10 clones derived from the same gene, the insert was amplified by PCR using M13 F/R primers, following the PCR conditions recommended by the cloning kit's manufacturer. The ten PCR products were tested against each other by mixing directly 4 I of each PCR products in a PCR tube, corresponding to a total of 45 pairwise combinations. An extra 8- $\mu$ l sample of a unique PCR product was also prepared to be used as a control for homoduplex patterns. All the mixtures were then placed in a Genamp PCR system 9700 (Applied Biosystem, Foster City, California). DNA strands were denatured at $96^{\circ} \mathrm{C}$ for $3 \mathrm{~min}$ and slowly cooled to $20^{\circ} \mathrm{C}$ at a rate of $0.25^{\circ} \mathrm{C} / \mathrm{s}$. The entire $8-\mu \mathrm{l}$ mixture was then loaded onto a $1 \%$ agarose gel and separated by electrophoresis for $90 \mathrm{~min}$ at $3.6 \mathrm{~V} / \mathrm{cm}$. Heteroduplex banding patterns were distinguished from among all of the 45 combinations and, eventually, the 10 clones could be discriminated and clustered based on the occurrence of detectable sequence polymorphisms. For both nuclear and mitochondrial genes and for each isolate, all the polymorphic inserts were selected and double-strand DNA sequencing was performed by the di-deoxy-chain termination method using a T3-T7 sequencing kit on a CEQ 2000 XL DNA sequencer (Beckman, Fullerton, California). Forward and reverse sequences were assembled in Sequencher 4.2 (Genecodes, Ann Arbor, MI) and aligned using an on-line version of ClustalW software (http://www.genebee.msu.su/clustal/ basic. html). The sequence obtained for the four nuclear and the two mitochondrial genes was deposited in the GenBank database (Table 3).

Table 4. List of the allele-specific primers designed in this study

\begin{tabular}{|c|c|c|c|}
\hline Gene & $\begin{array}{l}\text { Allele-specific primer } \\
(\mathrm{F}=\text { forward, } \mathrm{R}=\text { reverse) }\end{array}$ & Sequence $\left(5^{\prime}-3^{\prime}\right)$ & $\begin{array}{l}\text { Annealing } \\
\text { temperature }\left({ }^{\circ} \mathrm{C}\right)\end{array}$ \\
\hline$A S F$-like & $\begin{array}{l}\text { ASF-PAM1-Fa } \\
\text { ASF-PAM2-F } \\
\text { ASF-PAU-Fa } \\
\text { ASF-PCJC17a6-Fa } \\
\text { ASF-PC643e5-F } \\
\text { ASF-PCJC17c6-F }\end{array}$ & $\begin{array}{l}\text { GGT GCT GGA GGA AGT GCT T } \\
\text { ACC GCC ATC ACC ACC ATA } \\
\text { CAC CGC CAC AAC ATC CAC TC } \\
\text { ACT ATC TCC TAT GAT ACA CT } \\
\text { TCC TAT GCT ACA CAC TAA C } \\
\text { GAT ACA GTG TAG CAC CAT C }\end{array}$ & $\begin{array}{l}64 \\
60 \\
58 \\
54 \\
60 \\
58\end{array}$ \\
\hline$G P A 1$ & $\begin{array}{l}\text { GPA-PAM1-R } \\
\text { GPA-PAM2-R } \\
\text { GPA-PAU-R }\end{array}$ & $\begin{array}{l}\text { CTC GCA GCT CCC ACT GCG AG } \\
\text { ACA GCA CCA AAC AAA GTA CC } \\
\text { TCC CAC TAT AAA CAT GTC A }\end{array}$ & $\begin{array}{l}60 \\
60 \\
54\end{array}$ \\
\hline$R A S-Y p t$ & $\begin{array}{l}\text { RAS-PAM1-F } \\
\text { RAS-PAM1-R } \\
\text { RAS-PAM2-F } \\
\text { RAS-PAM2-R } \\
\text { RAS-PAU-F } \\
\text { RAS-PAU-R } \\
\text { RAS-PC643g1-F } \\
\text { RAS-PC643g1-R } \\
\text { RAS-PC643a2-F } \\
\text { RAS-PC643a2-R } \\
\text { RAS-PFR109h1-F } \\
\text { RAS-PFR 109h1-R }\end{array}$ & $\begin{array}{l}\text { AGA GGG ATA TAT TTG AGG TT } \\
\text { GTT GGA CCC GGG ACG GTC TTC } \\
\text { AGA GGG ATA TAT TTG CGG CT } \\
\text { TCA GCA ATC GGA GAG CAA GCT } \\
\text { A TTT ACT TGC AGC CGC AGG CT } \\
\text { ACC TAG GGC AGA CAA GCT AGT C } \\
\text { AGC GGT AGA CTG ACC ACA CCG } \\
\text { GCC TGG AGG TCA AAA CTT AG } \\
\text { GCT GCT AAC AGA CAG CAG AC } \\
\text { ATG AAG CAC TCC GAA CCG GT } \\
\text { TGT CGA GAG TGA TTT ATT } \\
\text { AA TGG CAA GGC TAG TTA CTA }\end{array}$ & $\begin{array}{l}60 \\
60 \\
60 \\
60 \\
58 \\
58 \\
60 \\
60 \\
60 \\
60 \\
60 \\
60\end{array}$ \\
\hline$T R P 1$ & $\begin{array}{l}\text { TRP-PAM1-R } \\
\text { TRP-PAM2-F } \\
\text { TRP-PAM2-R } \\
\text { TRP-PAU-F } \\
\text { TRP-PAU-R } \\
\text { TRP-PCJC17c3-F } \\
\text { TRP-PCJC17 } 3-R \\
\text { TRP-PFF309a9-F } \\
\text { TRP-PFF309a9-R }\end{array}$ & $\begin{array}{l}\text { CCT GTA GCA ACA GAG CAA TG } \\
\text { CCC GTT GCT GCG GCT GGC } \\
\text { GGT CGC CTA CAC CGC GTG } \\
\text { GTG CGT CGC TAG CCC ATC A } \\
\text { CGC CTA CAG AGC ATC ATA G } \\
\text { TGG ACG TAG AAG CCG CCA AG } \\
\text { CAG GCA TAT ACC GTT TCC AC } \\
\text { CTA CCT CCC TAA GCT TAT CA } \\
\text { ACG CAG CAT CAT AGA AAA T }\end{array}$ & $\begin{array}{l}60 \\
62 \\
62 \\
60 \\
60 \\
60 \\
60 \\
60 \\
60\end{array}$ \\
\hline
\end{tabular}

\footnotetext{
${ }^{a}$ Used in combination with gene-speci W c ASF-E2-2R as reverse primer.

${ }^{\mathrm{b}}$ Used in combination with gene-speci W c GPA-E1-1F as forward primer.

${ }^{c}$ Used in combination with gene-speci W c TRP-E1-1F as forward primer.
} 


\subsection{Phylogenetic analyses}

Phylogenetic analyses were performed with PAUP version 4.0 (Swofford, 2002), using the maximum parsimony method. Individual phylogenetic analyses were conducted for each mitochondrial and nuclear gene. Heuristic searches were performed using "tree-bisectionreconnection" (TBR) branch swapping algorithm, zero-length branches were collapsed and all characters equally weighted. Subsequent parsimony bootstrap analyses used 1000 replicates with TBR branch swapping.

\subsection{Design and testing of allele-specific PCR primers within the nuclear genes}

All the sequences obtained for each nuclear gene and for all of the 15 isolates were aligned using ClustalW. Based on different clusters of sequences, a series of allele-specific primers were manually designed from polymorphic regions or around insertion/deletion (indel) loci mainly located within introns. Some of the sequences could not be subjected to primer design due to an insufficient polymorphism level or scattered substitutions. To test the absence or the presence of the different alleles within the genome of the different Phytophthora isolates, all the primer pairs were tested by PCR, first with the 15-isolate panel to check their reliability and specificity, and then with all the isolates of the $P$. alni/Phytophthora spp. collection listed in Table 1. Allele-specific PCRs were carried out as described above for gene-specific amplification except that the $\mathrm{MgCl}_{2}$ concentration was increased to $2.2 \mathrm{mM}$ and that no BSA was used. The allele-specific annealing temperatures used are indicated in Table 4.

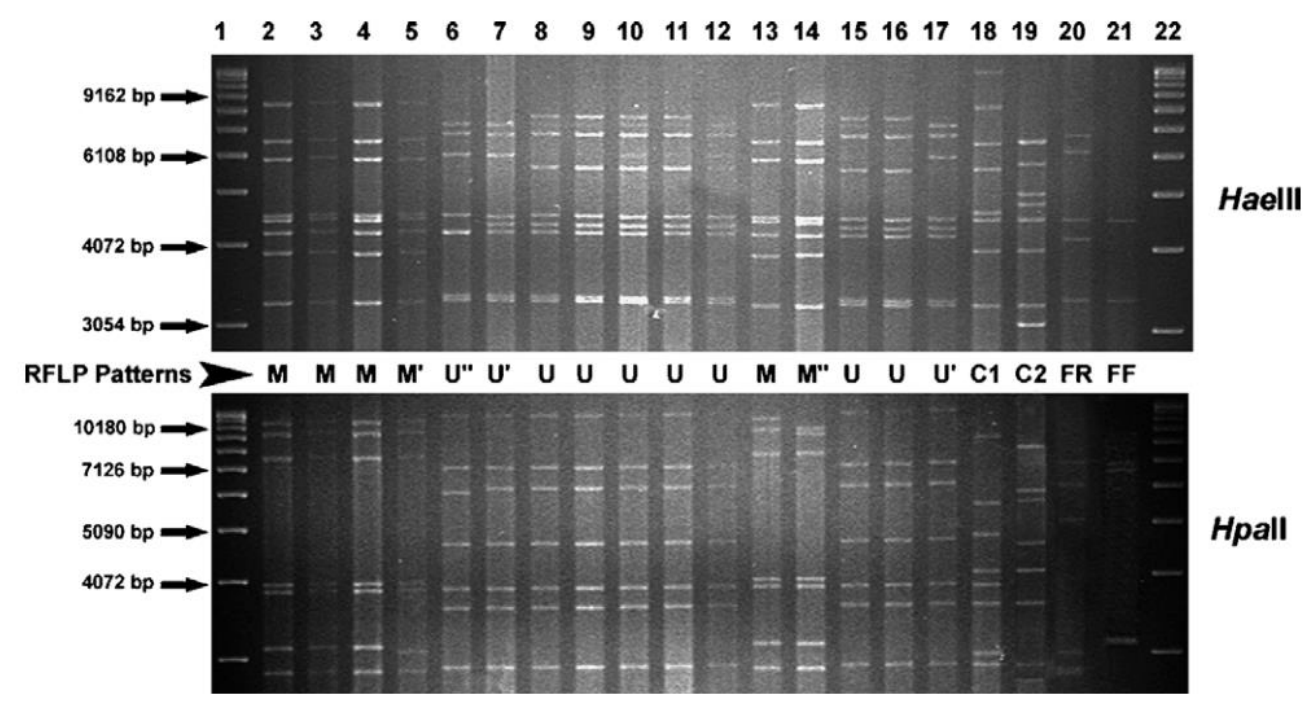

Fig. 1. Combination of the restriction patterns obtained by independent Haelll and Hpall digestions of total DNA from a series of $P$. alni subsp. multiformis (Pam), P. alni subsp. uniformis ( $P a u), P$. alni subsp. alni (Paa), P. cambivora $(P C), P$. fragariae var. rubi $(P f r)$, and $P$. fragariae var. fragariae (Pff) isolates. Six different combinations were resolved for P. alni and named M, M', M", U, U', and U'. Two different combinations were resolved for $\mathrm{Pc}$, i.e., $\mathrm{C} 1$ and $\mathrm{C} 2$, respectively, whereas a single combination was resolved for Pfr (FR) and for Pff (FF). Lanes 1 and 22, molecular standard $1 \mathrm{~kb}$ DNA Ladder (Invitrogen, Cergy Pontoise, France); lanes 2-5, Pam isolates PAM54, PAM71, PAM73, and PAM186; lanes 6-11, Pau isolates PAU60, PAU84, PAU87, PAU89, PAU142, and PAU188; lanes 12-17, Paa isolates PAA129, PAA130, PAA143, PAA151, PAA162, and PAA141; lanes 18 and 19, PC isolates PC643 and PCJC17; lane 20, Pfr isolate PFR109; lane 21, Pff isolate PFF309. 


\section{Results}

\subsection{Mitochondrial DNA patterns}

Digestion of total DNA with the two endonucleases generated patterns with several discrete bands. Both Haelll and Hpall revealed polymorphism in the mtDNA pattern of the isolates we tested. Four and five distinct patterns were revealed with Haelll and Hpall restrictions, respectively, among the studied isolates from the three subspecies of $P$. alni, respectively (Fig. 1). Combining the patterns of the two enzymes, isolates of the three $P$. alni subspecies could be placed in six groups: M, M', and M" groups encompassing only Paa and Pam isolates, and U, U', and U" groups, which included only Paa and Pau isolates. Most of the Pam isolates displayed the M pattern, whereas most of the Pau isolates displayed the $U$ pattern. The pattern M' was only observed for a single Pam isolate originating from Belgium (PAM186). Likewise, the two patterns U' and U' were both displayed by a single Pau isolate. Pattern U' was encountered in PAU84 from Sweden, whereas pattern U'" was encountered in PAU60 from France.

Five out of the six patterns, M, M', M', U, and U', were observed among the different Paa isolates we examined. No strong relationship could be established between the pattern observed and isolate origin or sampling date (Table 1). $M$ was the most frequent pattern encountered in the Paa isolates. By contrast, the M' pattern was characteristic of Paa isolates from Hungary, whereas M" was only found in Polish isolates. Despite being less frequent than $\mathrm{M}$, the $U$ pattern was also identified in Paa from locations throughout Europe, whereas the closely related U' pattern was only detected for one isolate originating in Austria (PAA141).

Additional patterns were resolved for $P$. cambivora isolates ( $\mathrm{C} 1$ and $\mathrm{C} 2)$ and for $P$. fragariae for which var. fragariae and var. rubi could be separated into FF and FR patterns, respectively (Fig. 1).

\subsection{Cloning and sequencing of the four nuclear and the two mitochondrial genes}

Each of the four nuclear genes (ASF-like, GPA1, RAS-Ypt, and TRP1) could be efficiently amplified using the designed exon-based primer pairs. Table 2 lists the series of primer pairs that best enabled the amplification of each gene. The two mitochondrial genes, cox1 and nadh1, were also successfully amplified using the gene-specific primers designed by Kroon et al. (2004).

Thanks to the heteroduplex analysis carried out for each individual isolate of the panel, several clones containing polymorphic inserts for each of the six genes could be selected.

The sequencing of the selected clones potentially containing different insert sequences showed that each isolate possessed one to four different alleles, depending on the nuclear gene, and either one or two slightly different sequences for the mitochondrial genes. For each of the four nuclear genes, all the coding regions of the sequences obtained were first translated and compared by sequence alignment to the published reference sequence(s) in order to check the identity of the cloned sequences (data not shown). The sequences obtained from the mitochondrial genes were compared using BLASTn software with the series of sequences published by Kroon et al. (2004) and shown to represent orthologs of cox1 and nadh1, as expected (data not shown).

\subsection{Sequence analysis for the nuclear genes}

Separate phylogenetic analyses were conducted for individual nuclear genes using all of the sequences obtained from the 15-isolate panel, and the retrieved ortholog sequences from $P$. ramorum and $P$. sojae were considered as outgroups.

For each of the four nuclear genes, a single allele was found in all of the Pau isolates. By contrast, two different alleles were systematically observed for all the Pam isolates on our panel, whereas at least two, and sometimes three different alleles, were present for all the $P a a$ isolates. All four phylogenetic trees showed the same clustering pattern regarding $P$. alni 

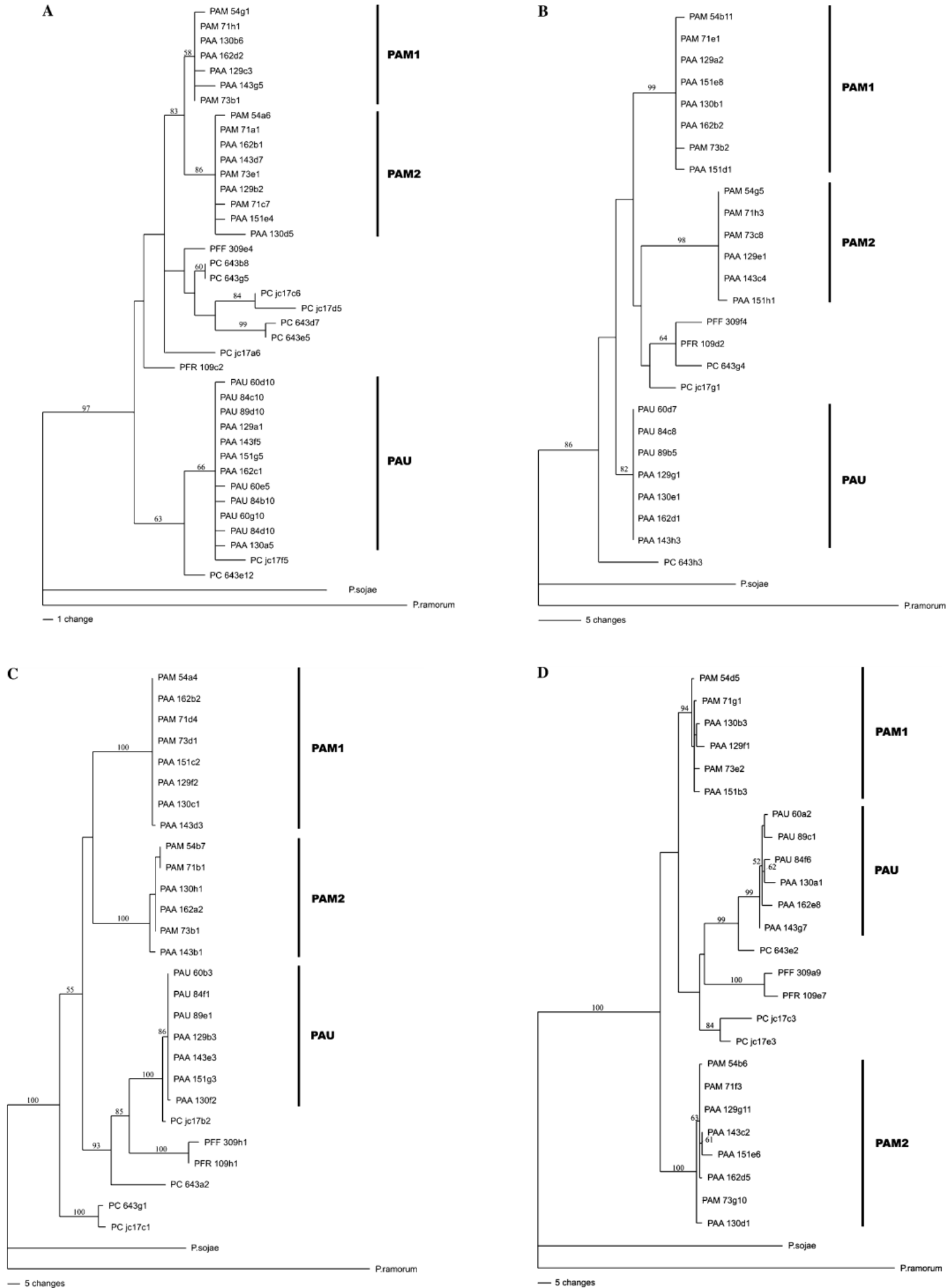

Fig. 2. Phylogenetic trees constructed using the parsimony method for each individual nuclear gene: ASF-like (A), GPA1 (B), RAS-Ypt (C), and TRP1 (D). Values given above the branches represent the bootstrap values from 1000 replicates; only values greater than $50 \%$ are shown. Clusters of similar $P$. alni sequences are defined on the right side of each tree. 
sequences (Fig. 2). Indeed, regardless of the gene considered, the different $P$. alni alleles could be split into three clusters, respectively, designated here as PAM1, PAM2, and PAU. For each of the four genes, PAM1 and PAM2 clusters only contained sequences originating from Paa and Pam isolates, whereas Pau clusters contained sequences originating from Paa and Pau isolates.

Single alleles were observed for the four studied genes for $P$. fragariae var. fragariae and $P$. fragariae var. rubi isolates. By contrast, one or two different alleles of GPA1, TRP1, and RAS-Ypt genes were identified for each $P$. cambivora isolate, whereas up to four different alleles of the ASF-like gene could be observed (Fig. 2A).

Some $P$. cambivora alleles were closely related to the Pau cluster but, except for ASFlike, were not included in this Pau cluster. The alleles identified for the two different varieties of $P$. fragariae clustered together in another group, different from those containing $P$. alni or $P$. cambivora sequences. Nevertheless, for the ASF-like gene, the respective alleles for the two varieties were separated (Fig. 2A).

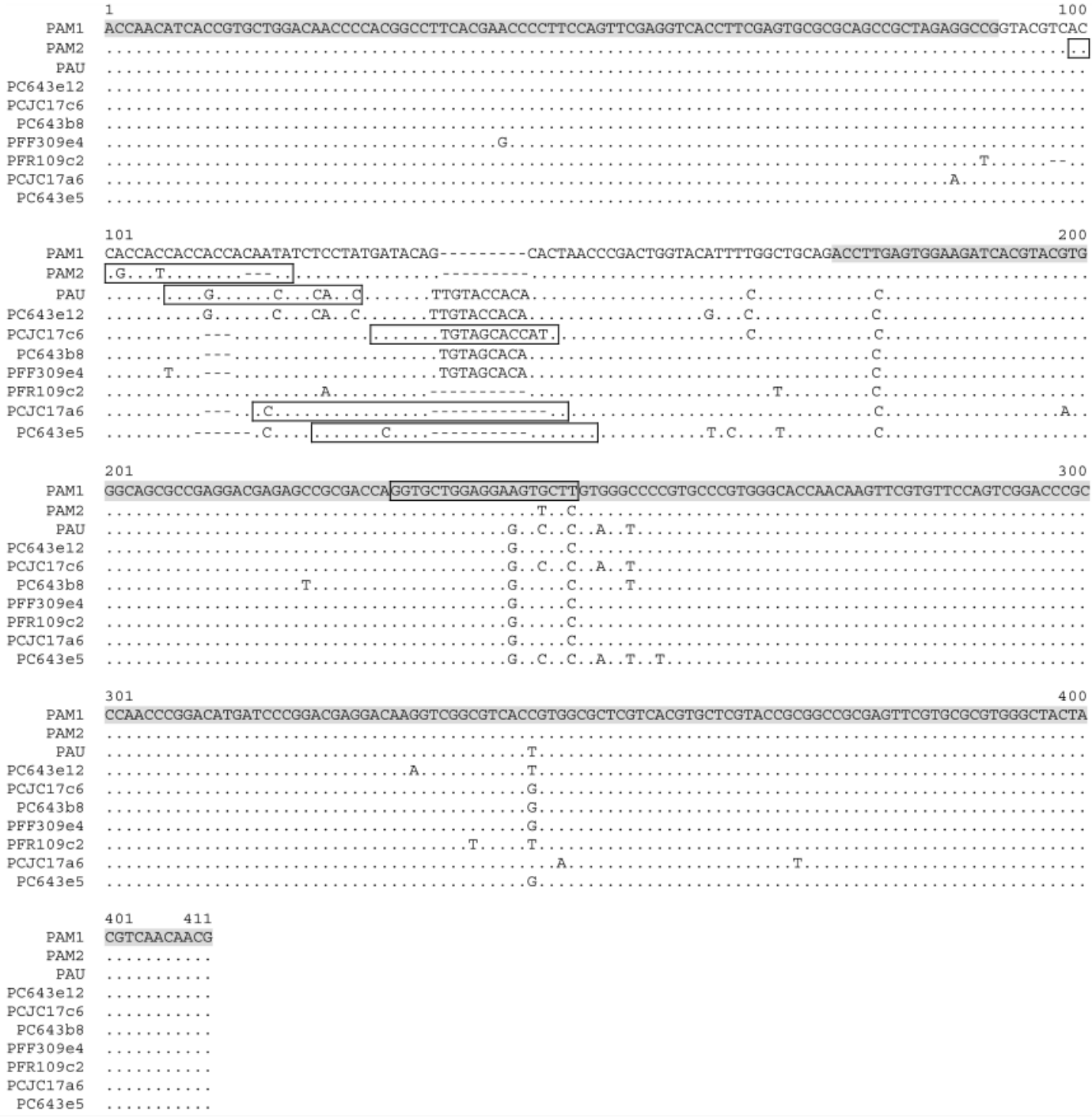

Fig. 3. Sequence alignment using the different groups of sequences collected from the 15isolate panel for the ASF-like gene. Sequences are designated according to the clusters designed from the phylogenetic trees or the clone from which they are derived (see Fig. 2A). Boxed characters indicate the regions from which allele-specific primers could be designed. Shaded regions correspond to exons. 


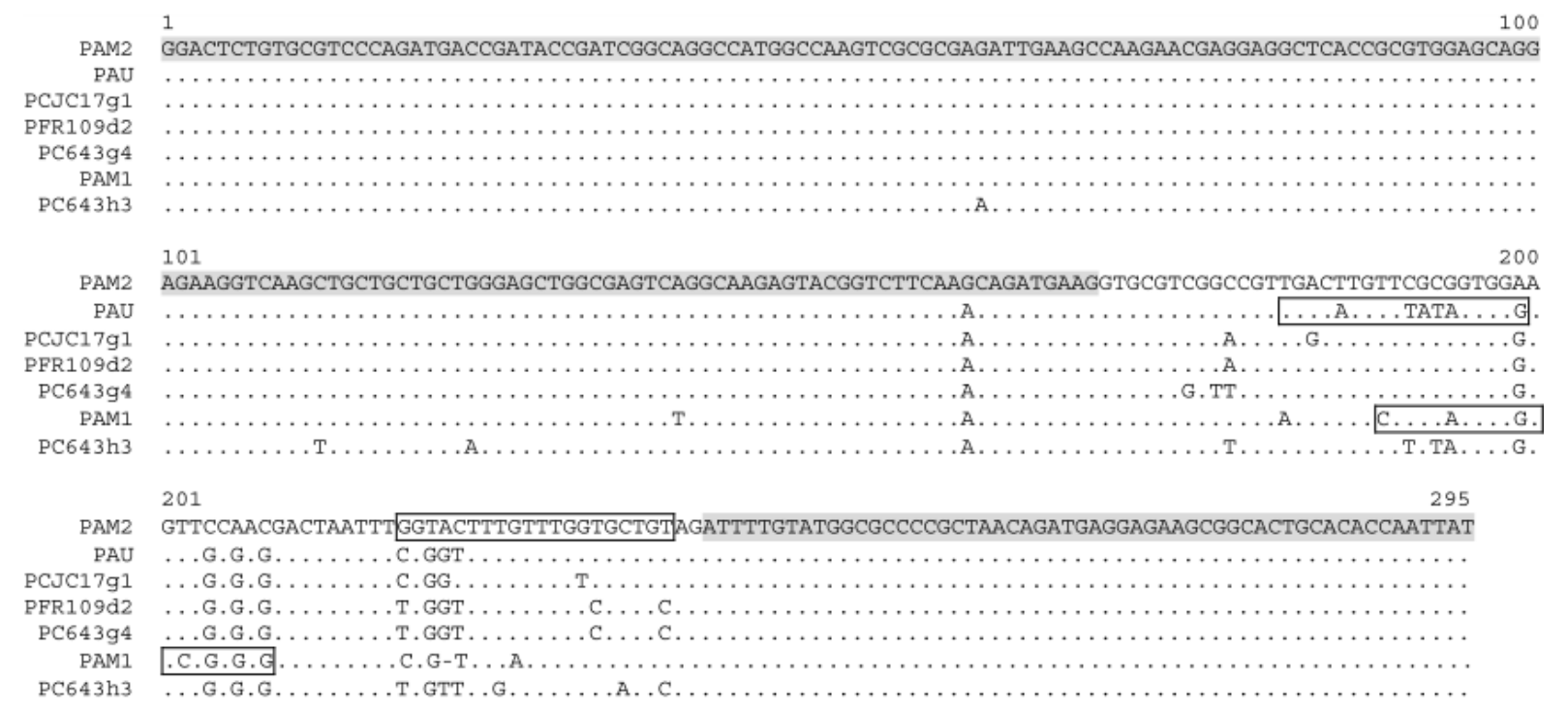

Fig. 4. Sequence alignment using the different groups of sequences collected from the 15isolate panel for the GPA1 gene. Sequences are designated according to the clusters designed from the phylogenetic trees or the clone from which they are derived (see Fig. 2B). Boxed characters indicate the regions from which allele-specific primers could be designed. Shaded regions correspond to exons.

\subsection{Allele-specific PCRs for the nuclear genes}

Sequence alignments using all the data collected for each nuclear gene and for each isolate showed that polymorphism mainly occurred in the intronic regions. These polymorphisms were used to design a series of allele-specific PCR primers for each nuclear gene (Figs. 3-6). For each nuclear gene, it was possible to design pairs of primers specific to each of the three clusters of $P$. alni alleles, i.e., PAM1, PAM2, and Pau, respectively (Table 4). Additionally, for the two related taxa, P. cambivora and P. fragariae, a series of PCR primers targeted regions that were specific to sequences obtained from at least one isolate and were named according to the clone they were designed from (Table 4). Unfortunately, it was sometimes impossible to design PCR primers from some of the sequences obtained from $P$. cambivora or $P$. fragariae because of possible cross-reactions with other sequences. Such sequences are indicated in italics in Table 5. Likewise, it was not possible to design primers that only targeted sequences present in one or the other variety of $P$. fragariae because of the very strong similarity between the sequences of the genes for the two varieties.

All the allele-specific primer pairs successfully yielded an amplicon of the expected size when tested with the DNA of the isolate the primers were designed from, confirming the reliability of the sequences. The testing of our Europe-wide collection of $P$. alni with the series of allele-specific PCR primers showed that, for each of the four nuclear genes, all the $P a a$ isolates possessed three alleles, referred to as PAM1, PAM2, and Pau, whereas all the Pam possessed two alleles, PAM1 and PAM2 (Table 5). By contrast, all the Pau isolates possessed only single alleles (PAU). These results confirm the previous results obtained by sequencing with the 15-isolate panel.

Based on these specific PCRs, single isolates of $P$. cambivora were shown to possess more alleles for each gene than previously derived from sequencing and displayed a more complex allelic pattern than expected for this species (Table 5). The occurrence of two different alleles of both TRP1 and RAS-Ypt genes, of three alleles of the GPA1 gene, and of two to four alleles for the ASF-like gene, could be derived from allele-specific PCRs. 
DGGAGATCGCGGCGCAGCGGCGCCTGGACGTGGAGGCCGCAARGCGCGTCGTGCCGGCCGAGCAGCTTCCCAAGAAGATCGAGAGCTCGGAGGCCGTC

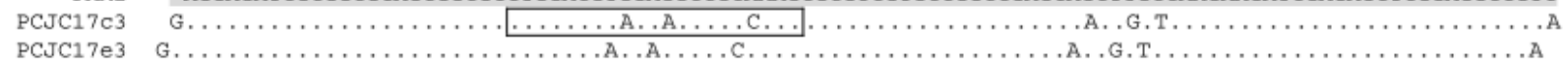
GA.

TACGGCTCGGCGCTGCGCGTGCTCG-ACCGCCTCAACGCGCCCGTGGTGCGTCGCTAGTCCCGAACGAAGGGGGAAGAGGCCTCGCTGACGTGTTAATTG

Fig. 6. Sequence alignment using the different groups of sequences collected from the 15isolate panel for the TRP1 gene. Sequences are designated according to the clusters designed from the phylogenetic trees or the clone from which they are derived (see Fig. 2D). Boxed characters indicate the regions from which allele-specific primers could be designed. Shaded regions correspond to exons.

\subsection{Sequence analysis for the mitochondrial genes}

The mitochondrial gene sequences obtained with the limited six-isolate panel were aligned with the sequences of cox1 and nadh1 previously published by Kroon et al. (2004) 
for $P$. alni subsp. multiformis (isolate PD92/1471, formerly designated as $P$. hybrid-Dutch variant) (GenBank Accession Nos. AY564168 and AY563995, respectively), $P$. fragariae var. fragariae (GenBank Accession Nos. AY564177 and AY564178, and AY564004 and AY564005, respectively), and P. fragariae var. rubi (GenBank Accession Nos. AY564179 and AY564180, and AY564006 and AY564007, respectively).

Table 5. Occurrence and distribution of the different alleles for the four nuclear genes in the genome of the different subspecies of $P$. alni, $P$. cambivora, and the two varieties of $P$. fragariae, as inferred from allele-specific PCR tests

\begin{tabular}{|c|c|c|c|c|}
\hline Species & $A S F$-like & $G P A 1$ & $R A S-Y p t$ & $T R P 1$ \\
\hline P. alni subsp. alni & $\begin{array}{l}\text { ASF-PAM1 } \\
\text { ASF-PAM } 2 \\
\text { ASF-PAU }\end{array}$ & $\begin{array}{l}\text { GPA-PAM1 } \\
\text { GPA-PAM } 2 \\
\text { GPA-PAU }\end{array}$ & $\begin{array}{l}\text { RAS-PAM1 } \\
\text { RAS-PAM2 } \\
\text { RAS-PAU }\end{array}$ & $\begin{array}{l}\text { TRP-PAM1 } \\
\text { TRP-PAM2 } \\
\text { TRP-PAU }\end{array}$ \\
\hline P. alni subsp. multiformis & $\begin{array}{l}\text { ASF-PAM1 } \\
\text { ASF-PAM2 }\end{array}$ & $\begin{array}{l}\text { GPA-PAM1 } \\
\text { GPA-PAM2 }\end{array}$ & $\begin{array}{l}\text { RAS-PAM1 } \\
\text { RAS-PAM2 }\end{array}$ & $\begin{array}{l}\text { TRP-PAM1 } \\
\text { TRP-PAM2 }\end{array}$ \\
\hline P. alni subsp. uniformis & ASF-PAU & GPA-PAU & RAS-PAU & TRP-PAU \\
\hline P. cambivora & $\begin{array}{l}\text { ASF-PAU } \\
\text { ASF-PCJC17a } 6^{\mathrm{a}} \\
\text { ASF-PC } 643 \mathrm{e} 5^{\mathrm{b}} \\
\text { ASF-PCJC17c6 } \\
A S F-P C 643 b 8^{\mathrm{c}}\end{array}$ & $\begin{array}{l}\text { GPA-PCJC17gI } \\
\text { GPA-PC643h3 } \\
\text { GPA-PC643g } 4\end{array}$ & $\begin{array}{l}\text { RAS-PAU }^{\mathrm{a}} \\
\text { RAS-PC643g1 } \\
\text { RAS-PC643a2 }^{\mathrm{b}}\end{array}$ & 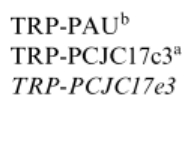 \\
\hline P. fragariae var. fragariae & $A S F-P F F 309_{e} 4$ & GPA-PFF309g4 & RAS-PFR 109h1 & TRP-PFF309a9 \\
\hline P. fragariae var. rubi & $A S F-P F R 109_{c} 2$ & GPA-PFR109d2 & RAS-PFR 109h1 & TRP-PFF309a9 \\
\hline Phytophthora spp. & n.p.s. & n.p.s. & n.p.s. & n.p.s. \\
\hline Pythium spp. & n.p.s. & n.p.s. & n.p.s. & n.p.s. \\
\hline
\end{tabular}

n.p.s., no positive signal when tested with all the available allele-speci W c primer pairs

${ }^{a}$ Except isolate PC643.

${ }^{b}$ Positive only for isolates PC643 and PC463.

${ }^{\mathrm{C}}$ Italics indicate alleles of genes obtained by cloning and sequencing, and for which PCR primers could not be designed.

Separate phylogenetic analyses were conducted for each mitochondrial gene using all the sequences obtained with Paa, Pam, Pau, and Pc and the retrieved sequences from Pam, Pff , and Pfr. For the two mitochondrial genes, either a single or two nearly identical (1-3 substitutions) sequences were obtained for each individual isolate. For the two mitochondrial genes, the clusters regarding $P$. alni sequences were the same (Figs. 7A and B). Sequences from PAM54 and PAA130, if not identical, clustered together in the mtPAM cluster, along with sequences of Pam isolate PD92/ 1471 (Kroon et al., 2004), whereas another cluster called mtPAU gathered the sequences from PAU60 and PAA129. Sequences obtained from $P$. cambivora isolates significantly differed from those forming the two $P$. alni clusters. Moreover, sequences of isolates PC643 and PCJC17 were clearly separated in both phylogenetic trees. Sequences of $P$. fragariae retrieved from GenBank (Kroon et al., 2004) did not cluster with either $P$. alni or $P$. cambivora's sequences.

\section{Discussion}

\subsection{Allelic diversity within P. alni}

This study performed on a large Europe-wide collection of $P$. alni isolates demonstrated that three different alleles of each of the four studied nuclear genes were present in the $P$. alni subsp. alni (Paa) genome. Two of these alleles, PAM1 and PAM2, were the same as those found in all the studied $P$. alni subsp. multiformis (Pam) isolates, whereas the third allele of each gene, i.e., Pau, corresponded to the single alleles found in all of the $P$. alni subsp. uniformis (Pau) isolates. 

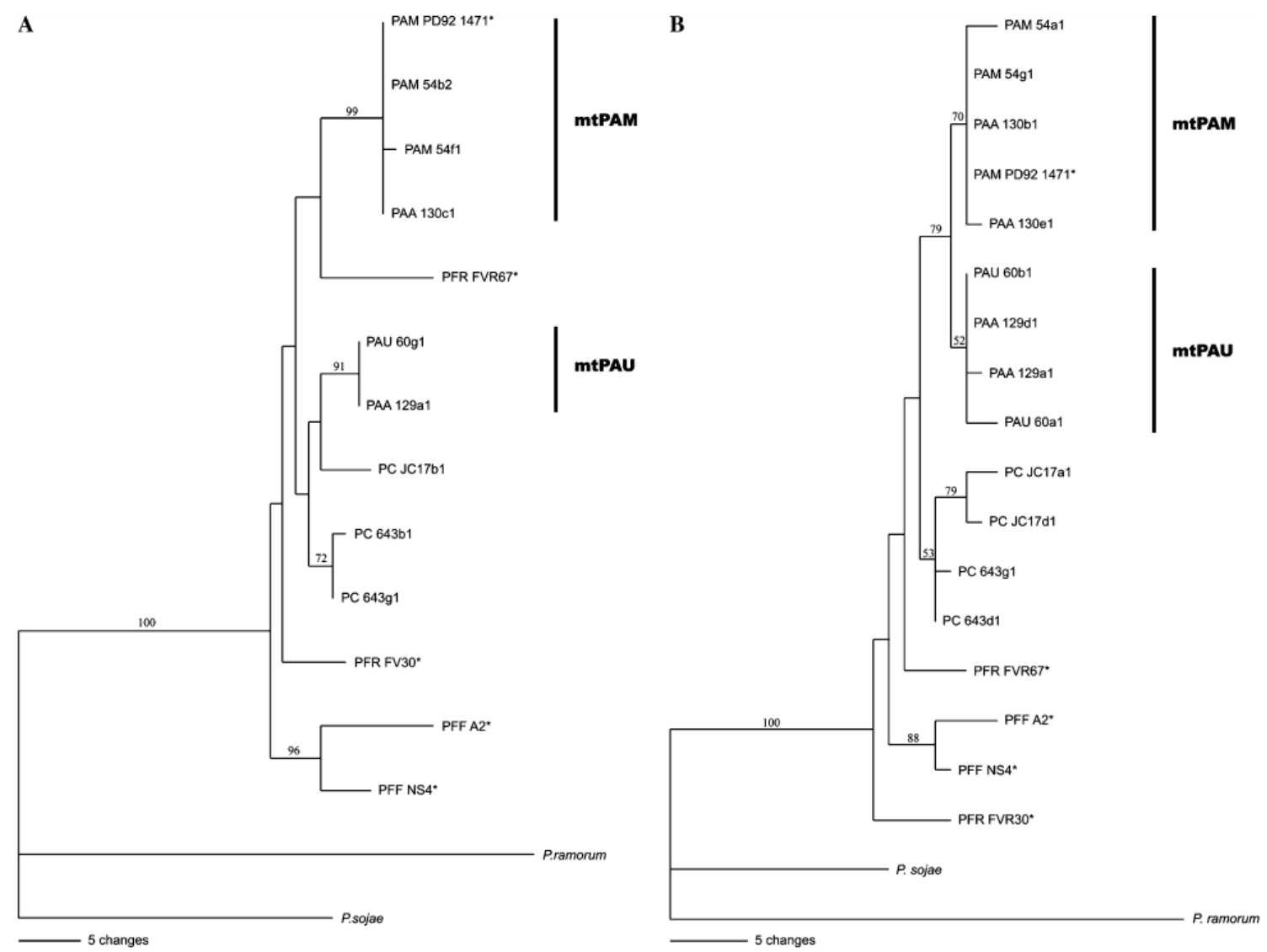

Fig. 7. Phylogenetic trees constructed using the parsimony method for each individual mitochondrial gene: cox1 (A) and nadh1 (B). Values given above the branches represent the bootstrap values from 1000 replicates; only values greater than $50 \%$ are shown. Sequences labeled with an asterisk are retrieved from the work of Kroon et al. (2004) and correspond to cox1 sequences for Pam isolate PD92/1471 (AY564168), Pff isolate A2 (AY564177), Pff isolate NS4 (AY564178), Pfr isolate FVR67 (AY564179), and Pfr isolate FVR30 (AY564180) (A), and to nadh1 sequences for Pam isolate PD92/1471 (AY563995), Pff isolate A2 (AY564004), Pff isolate NS4 (AY564005), Pfr isolate FVR67 (AY564006), and Pfr isolate FVR30 (AY564007) (B).

The presence of single alleles in all the Pau isolates and the low level of polymorphism observed suggest that this subspecies is probably close to homozygosity for the nuclear genes we studied. These data are consistent with this subspecies being near-diploid and with its high phenotypic and genetic uniformity (Brasier et al., 1999).

By contrast, two significantly divergent alleles (PAM1 and PAM2) of the four nuclear genes were observed in all the Pam isolates we studied. If, by extension, two alleles of most of the nuclear genes are present in Pam, then this subspecies should normally be neartetraploid, which would be in disagreement with the ploidy levels $(2 n+4$ to $2 n+7)$ determined with the acetoorcein method by Brasier et al. (1999). A first explanation is that Pam is homoploid, i.e., near-diploid for the genus Phytophthora, but heterozygous with two alleles, PAM1 and PAM2, as diploid orthologs, probably on homolog chromosomes. As a result, Pam could be a cryptic polyploid hybrid species that regained a level of ploidy close to diploidy. However, Pam is homothallic and constant selfing should normally drive homothallic species to a homozygous state (Goodwin, 1997). Nevertheless, despite the homothallic nature of Pam, germinating oospores were not observed for any of the $P$. alni subspecies during an in vitro study (Delcan and Brasier, 2001) and, therefore, these species could be reproducing only asexually, which would maintain a high level of heterozygosity. A second 
hypothesis would be that the occurrence of two alleles of the studied nuclear genes in Pam has been generated by autopolyploidization. Indeed, the studied nuclear genes are not physically linked since they are located on different scaffolds in the $P$. sojae or $\mathrm{P}$. ramorum genomes (Table 2). Therefore, the occurrence of multiple polymorphic sequences might not have arisen by gene duplication, generating paralogs, because the simultaneous duplication of four physically unlinked genes seems very unlikely. Finally, it cannot be inferred from our data whether or not the presence of two alleles of the four studied nuclear genes arose from an ancient autopolyploidization generating series of homologous alleles in a Pam ancestor, followed by divergent evolution between the two respective genes, or was generated by an ancient reticulation event such as interspecific hybridization.

The presence of three alleles in Paa and the level of divergence between their respective sequences, as high as the level of divergence between the ortholog sequences for each of the studied genes in $P$. cambivora and $P$. fragariae, are consistent with Paa being allopolyploid, as demonstrated by Brasier et al. (1999). Indeed, intraspecific polyploidization might not have generated three such divergent alleles and, therefore, the occurrence of multiple alleles in Paa would be the result of at least one reticulation. The three alleles are probably located on homoelogue chromosomes, following a reticulation event. Overall, the data from the nuclear gene are in full agreement with previous research using isozyme analysis. Nagy et al. (2003), as well as Brasier et al. (2004), revealed a trisomic state at the glucose-6-phosphate isomerase (Gpi) locus for Paa, which is consistent with the cooccurrence of three different alleles of the four nuclear genes. Likewise, heterozygosity at the Gpi locus for Pam and homozygosity at three different enzyme loci, including Gpi, for Pau (Brasier et al., 2004), are consistent with our findings of two and single alleles for Pam and $P a u$, respectively, for the four nuclear genes.

This multilocus analysis conducted on a Europe-wide collection of hybrids showed that the genome of the parental species has been conserved to a high degree in Paa and Pam. Thus, the co-existence of two and three alleles of most of the nuclear genes, probably located on respective homoelogue chromosomes, may be hypothesized. This co-existence does not mean that each allele is actually expressed, but may be an explanation why Pam and Paa are reported to be phenotypically more unstable than Pau (Delcan and Brasier, 2001; De Merlier et al., 2005), in which only single alleles were found. Paa is the most frequent subspecies in Europe at this time (Brasier, 2003; loos, unpublished results) and seems to propagate essentially by vegetative reproduction through the dissemination of zoospores. This subspecies cannot diversify by outcrossing, nor can it use meiosis to mitigate the accumulation of deleterious mutations known as Muller's ratchet (Muller, 1964). However, genetic redundancy in this hybrid and in Pam, to a lesser extent, might mask some deleterious mutations and may also enable the hybrid to be more fit in its ecological niche, i.e., to maintain itself as an aggressive pathogen on alder. For example, this type of selective advantage of hybrid species was demonstrated for a fungal endophyte species, Neotyphodium coenophialum, which also has three ancestors involved in two separate hybridization events (Moon et al., 2004). Based on the allelic distribution of the studied nuclear genes, it appears that (i) either the Paa genome contributed to the genomes of Pam and Pau by descent, or (ii) conversely, that Pam and Pau contributed to the genome of Paa by hybridization.

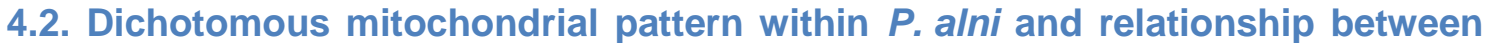 the three subspecies}

The mitochondrial DNA features combined with the different nuclear allelic patterns found indicate that Pau and Pam might not have arisen from the genetic breakdown of Paa, as previously hypothesized by Delcan and Brasier (2001). Indeed, Paa isolates have all three different alleles of the nuclear genes we studied, and all display either an M/M'/M" or a U/U' mtDNA pattern. On the other hand, all the Pam isolates possess two of these alleles (PAM1 and PAM2) and display two closely related mtDNA patterns, M or M', whereas all the Pau isolates possess single alleles (PAU), and display three closely related mtDNA patterns, $U$, 
U', or U'. If Pam and Pau had originated from Paa through segregation, then other combinations of nuclear and mitochondrial DNA would be expected, which has not been the case so far.

The mitochondrial DNA analysis showed that all the Paa isolates tested displayed either a pattern identical to Pam isolates (M/M'/M') or to Pau isolates (U/U'). The two mitotypes are present throughout Europe with no obvious geographical or sampling time pattern (Table 1). Moreover, further analyses carried out on additional French Paa isolates showed that the mitotypes M' and U' were also present in France (loos, unpublished data). Furthermore, the sequencing of the cox 1 and nadh1 mitochondrial genes demonstrated the occurrence of a unique mitotype within $P$. alni isolates. Moreover, the sequences of individual Paa isolates, i.e., PAA129 or PAA130, cluster either with those of Pau (PAU60) or with those of Pam (PAM54), respectively, which is therefore fully consistent with the dichotomous distribution of the mtDNA patterns resolved by RFLP (see Table 1).

Some of the mtDNA RFLP patterns obtained with Haelll were identical to those obtained by Nagy et al. (2003) on the same subspecies; however, we obtained more patterns than previously described because we screened a broader collection of isolates. The occurrence of several closely related mtDNA patterns within each subspecies of P. alni, i.e., $M, M^{\prime}$, and $M^{\prime \prime}$, on the one hand, and $U, U^{\prime}$, and $U^{\prime \prime}$, on the other hand, is not surprising. Indeed, these patterns only differed by the size of one or two restriction fragments, which could be explained by insertion-deletion events and seems consistent with the level of intraspecific polymorphism already observed in other species such as $P$. infestans (Goodwin, 1991) or P. parasitica (Lacourt et al., 1994). By contrast, the two mitotype groups, M/M'/M"' and $U / U^{\prime} / U^{\prime \prime}$, differed from each other by at least six restriction fragments for each enzyme, indicating a large divergence between the two mitotype groups.

Finally, the co-segregation of mtDNA along with nuclear patterns could also be explained either by linkage between mtDNA and the nuclear genes studied or by a poorer viability of the "missing" hybrids combining U/U'/U" mtDNA and PAM1/PAM2 nuclear DNA or M/M'/M" mtDNA and Pau nuclear DNA. However, linkage between mtDNA and four physically unrelated nuclear genes seems very unlikely, whereas poorer viability of the "missing" hybrids remains possible but difficult to demonstrate experimentally. Whittaker et al. (1994) proved that mtDNA was uniparentally inherited from A1 x A2 matings in $P$. infestans and that there was no evidence for biparental inheritance, recombination or segregation of mitotypes, regardless of the ages of the crossings. Later, Man in't Veld et al. (1998) demonstrated that only mtDNA from $P$. nicotianae was present in the natural hybrid $P$. nicotianae $\times$ P. cactorum isolates. Accordingly, we favor the most parsimonious hypothesis that Paa may have arisen via hybridization of two taxa close to Pau and Pam, if not Pau and Pam themselves. This hypothesis is well supported by other investigations conducted on a series of elicitin genes, which belong to a multigenic family encoding polypeptides specific to the genus Phytophthora and a few Pythium species (loos et al., in preparation). Moreover, since the mitochondrial DNA is only uniparentally inherited following crossing, this hypothesis might explain why Paa isolates display different mitochondrial DNA patterns, whereas they all possess the same three alleles for each of the four nuclear genes. From this point of view, sexual, rather than somatic, hybridization is more likely to have occurred.

Furthermore, the occurrence of significantly different mtDNA patterns among Paa isolates and the fact that these patterns are shared either with Pau or Pam also implies that different hybridization events might have occurred. Moreover, the uniparental inheritance of mtDNA and the occurrence of two groups of mitotypes in Paa suggest that the hybridization events may have occurred in both directions. Furthermore, different mtDNA patterns combined with intraspecific variation were observed among the Paa isolates that we gathered from different isolation dates. This suggests that the spread of this subspecies, within different countries and throughout Europe, might not be attributable to a single clone, as hypothesized by Brasier et al. (1995) and Nagy et al. (2003). The occurrence of multiple 
hybridization events has already been demonstrated for other natural Phytophthora hybrids between $P$. nicotianae and $P$. cactorum, probably generated in hydroponic systems of greenhouses in the Netherlands (Bonants et al., 2000).

Whether or not Pau and Pam are the direct progenitors of Paa cannot be inferred from our nuclear and mitochondrial investigations. Pam and Pau are far less frequently isolated from alder lesions than Paa, regardless of their geographical origins (Brasier et al., 2004) and have proved to be significantly less aggressive on alder bark than Paa (Brasier and Kirk, 2001). One of the first Pam isolates sampled in the Netherlands was found in 1995 in soil in a natural alder stand where none of the alders showed any symptoms of Phytophthora disease (Streito, 2003), while Santini et al. (2003) reported the isolation of Pau from asymptomatic alder seedlings. Therefore, Pam and Pau, or Pam- and Pau-like species, might have existed for a long time on-or in the vicinity of - alder trees before the recent emergence of large-scale decay in the European alder population. The occurrence of these species in the past might not have been noticed because of the lack of conspicuous symptoms or declines of whole trees.

Considering the wide extant hybrid zone where the different subspecies of $P$. alni disseminate, the introgression may presumably continue through further reticulation events or backcrossings. Despite the fact that the Paa, Pam, and Pau isolates we tested only displayed a limited level of intraspecific nuclear polymorphism, the occurrence of new genotypes cannot be ruled out as a possibility. For instance, Jung and Blaschke (2004) and Brasier et al. (2004) reported the occurrence of additional major variants of Pam and minor variants of $P a u$, presumed to have been generated either by backcrossing or reassortments of the hybrid genome.

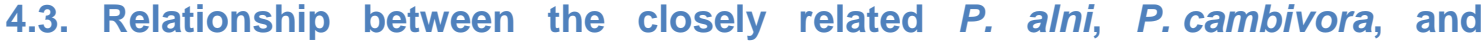

\section{$P$. fragariae}

Since no allele present in the two varieties of $P$. fragariae for the four nuclear and the two mitochondrial genes we studied was observed in any $P$. alni subspecies, our results confirm that this species is not among the parental species of $P$. alni, as previously suggested by Brasier (2003). Suggested to be one of the progenitors of $P$. alni by Brasier et al. $(1999,2004), P$. cambivora was included in this study in order to unravel the relationship between the three subspecies of $P$. alni, only pathogenic on alder, and P. cambivora, pathogenic on numerous deciduous trees, but not on alder (Brasier and Kirk, 2001; Santini et al., 2003). Our results do not support the hypothesis that $P$. cambivora is directly involved as a parental species for $P$. alni. Although $P$. cambivora is undoubtedly close to Pau and Paa, with at least one allele of $P$. cambivora close to the allele shared by Paa and Pau for the four nuclear genes, there is never complete identity. Since the hybrid is believed to be in its nascent state (Brasier et al., 1999), one might expect to find alleles of the parental species for each nuclear gene in the hybrid genome. The series of Pau allele-specific primers designed in this study yielded a PCR product when tested with several isolates of $P$. cambivora. Nevertheless, sequencing of genes showed that within the Pau cluster, polymorphism occurred between the target regions of the two primers. In particular, $P$. cambivora sequences could be differentiated from $P$. alni sequences by several substitutions but, at the same time, could not be discriminated by Pau-specific PCRs. Therefore, our sequence data suggest that $P$. cambivora may not be directly involved as a parental species but it could still be one parental species of an ancient Pau-like species that has evolved. Nevertheless, considering the unexpected genetic variability among French isolates of $P$. cambivora, the involvement of another particular genotype of $P$. cambivora, either exotic or endemic to Europe, cannot be ruled out as a possibility. Further sequencing studies using the allele-specific primers designed in this study with a broader collection of $P$. cambivora isolates could be of great interest in order to validate such a hypothesis. $P$. cambivora isolates exhibited more alleles than expected for a typical diploid species, for example, with up to four different alleles of the ASF-like gene and two significantly different alleles of the RAS-Ypt gene. This is in agreement with previous observations based on 
ribosomal DNA where ITS polymorphisms were revealed within individual isolates (Brasier et al., 1999; Cooke and Duncan, 1997) and suggests that independent gene duplications generating paralogs might have occurred for that species and/or, that $P$. cambivora might have been involved in reticulation events in the past.

\section{Acknowledgments}

We are very grateful to Dr. S. Jeandroz (Henri Poincaré University, Nancy) for critically reviewing the manuscript before submission and to Dr. Y. Brygoo (INRA Versailles) for helpful comments about this research. We thank our European colleagues for sharing Phytophthora isolates with us and Dr. C. Delatour for the forest Phytophthora species he provided. This research was partly funded by a grant from the Agence de l'Eau Rhin-Meuse.

\section{References}

Arnold, M.L., 2004. Natural hybridization and the evolution of domesticated, pest and disease organisms. Mol. Ecol. 13, 997-1007.

Bonants, P.J.M., Hagenaar-de Weerdt, M., Man in't Veld, W.A., Baa yen, R.P., 2000. Molecular characterization of natural hybrids of Phytophthora nicotianae and P. cactorum. Phytopathology 90, 867-874.

Brasier, C.M., 2003. The hybrid alder Phytophthora: genetic status, pathogenicity, distribution and competitive survival. In: Gibbs, J.N., Van Dijk, C., Webber, J.F. (Eds.), Phytophthora Disease of Alder in Europe. Forestry Commission Bulletin No. 126. HMSO, Edinburgh, pp. 39-54.

Brasier, C.M., Kirk, S., 2001. Comparative aggressiveness of standard and variant hybrid alder Phytophthoras, Phytophthora cambivora and other Phytophthora species on bark of Alnus, Quercus and other woody hosts. Plant Pathol. 50, 218-229.

Brasier, C.M., Cooke, D.E.L., Duncan, J.M., 1999. Origin of a new Phytophthora pathogen through interspecific hybridization. Proc. Natl. Acad. Sci. USA 96, 5878-5883.

Brasier, C.M., Kirk, S.A., Delcan, J., Cooke, D.E.L., Jung, T., Man in't Veld, W.A., 2004. Phytophthora alni sp. nov. and its variants: designa tion of emerging heteroploid hybrid pathogens spreading on Alnus trees. Mycol. Res. 108, 1172-1184.

Brasier, C.M., Rose, J., Gibbs, J.N., 1995. An unusual Phytophthora associated with widespread alder mortality in Britain. Plant Pathol. 44, 999-1007.

Burnett, J.H., 1983. Speciation in fungi. Trans. Br. Mycol. Soc. 81, 1-14.

Chen, Y., Roxby, R., 1996. Characterization of a Phytophthora infestans gene involved in vesicle transport. Gene 181, 89-94.

Cooke, D.E.L., Duncan, J.M., 1997. Phylogenetic analysis of Phytophthora species based on ITS1 and ITS2 sequences of the ribosomal RNA gene repeat. Mycol. Res. 101, 667-677.

Cooke, D.E.L., Duncan, J.M., Williams, N.A., Hagenaar-de-Weerdt, M., Bonants, P.J.M., 2000. Identification of Phytophthora species on the basis of restriction enzyme fragment analysis of the internal transcribed spacer regions of ribosomal RNA. EPPO Bull. 30, 519-523.

Delcan, J., Brasier, C.M., 2001. Oospore viability and variation in zoospore and hyphal tip derivatives of the hybrid alder Phytophthoras. Forest Pathol. 31, 65-83.

De Merlier, D., Chandelier, A., Debruxelles, N., Noldus, M., Laurent, F., Dufays, E., Claessens, H., Cavelier, M., 2005. Characterization of alder Phytophthora isolates from Wallonia and development of SCAR primers for their specific detection. J. Phytopathol. 153, 99-107.

Gibbs, J.N., 1995. Phytophthora root disease of alder in Britain. EPPO Bull. 25, 661-664.

Gibbs, J., Van Dijk, C., Webber, J., 2003. Phytophthora disease of alder in Europe. Forestry Commission Bulletin 126, Edinburgh, 82 pp.

Goodwin, S.B., 1991. DNA polymorphisms in Phytophthora infestans: the Cornell experience. In: Lucas, J.A., Shattock, R.C., Shaw, D.S., Cooke, L.R. (Eds.), Phytophthora. Cambridge University Press, Cambridge, pp. 256-271.

Goodwin, S.B., 1997. The population genetics of Phytophthora. Phytopathology 87, 462-473.

loos, R., Husson, C., Andrieux, A., Frey, P., 2005. SCAR-based PCR primers to detect the hybrid pathogen Phytophthora alni and its subspecies causing alder disease in Europe. Eur. J. Plant Pathol. 112, 323-335. 
loos, R., Panabières, F., Andrieux, A., Frey, P. (2007). Overlapping elicitin genes patterns resolved within the hybrid oomycete Phytophthora alni and the related species P. cambivora and P. fragariae, Applied and Environmental Microbiology, 73, 5587-5597.

Jung, T., Blaschke, M., 2004. Phytophthora root and collar rot of alders in Bavaria: distribution, modes of spread and possible management strategies. Plant Pathol. 53, 197-208.

Karlowsky, P., Prell, H.H., 1991. The TRP1 gene of Phytophthora parasitica encoding indole-3glycerolphosphate synthase- $\mathrm{N}$-(5-phosphori-bosyl) anthranilate isomerase: structure and evolutionary distance form homologous fungal genes. Gene 109, 161-165.

Kroon, L.P.N.M., Bakker, F.T., van den Bosch, G.B.M., Bonants, P.J.M., Flier, W.G., 2004. Phylogenetic analysis of Phytophthora species based on mitochondrial and nuclear DNA sequences. Fungal Genet. Biol. 41, 766-782.

Lacourt, I., Panabières, F., Marais, A., Venard, P., Ricci, P., 1994. Intraspecific polymorphism of Phytophthora parasitica revealed by analysis of mitochondrial DNA restriction fragment length polymorphism. Mycol. Res. 98, 562-568.

Laxalt, A.M., Latijnhouwers, M., van Hulten, M., Govers, F., 2002. Differential expression of G protein alpha and beta subunit genes during development of Phytophthora infestans. Fungal Genet. Biol. 36, 137-146.

Man in't Veld, W.A., Veenbaas-Rijk, W.J., llieva, E., De Cock, A.W.A.M., Bonants, P.J.M., Pieters, R., 1998. Natural hybrids of Phytophthora nicotianae and $P$. cactorum demonstrated by isozyme analysis and random amplified polymorphic DNA. Phytopathology 88, 922-929.

Miller, P.M., 1955. V-8 juice agar as a general purpose medium for fungi and bacteria. Phytopathology $45,461-462$.

Moon, C.D., Craven, K.D., Leuchtmann, A., Clement, S.L., Schardl, C.L., 2004. Prevalence of interspecific hybrids amongst asexual fungal endophytes of grasses. Mol. Ecol. 13, 1455-1467.

Muller, H.J., 1964. The relation of recombination to mutational advance. Mutat. Res. 1, 2-9.

Munakata, T., Adachi, N., Yokoyama, N., Kuzuhara, T., Horikoshi, M., 2000. A human homologue of yeast anti-silencing factor has histone chaperone activity. Genes Cells 5, 221-233.

Nagy, Z.A., Bakonyi, J., Ersek, T., 2003. Standard and Swedish variant types of the hybrid alder Phytophthora attacking alder in Hungary. Pest Manag. Sci. 59, 484-492.

Olson, A., Stenlid, J., 2002. Pathogenic fungal species hybrid infecting plants. Microbes Infect. 4, 1353-1359.

Pinar, A., Ahkee, S., Miller, R.D., Ramirez, J.A., Summersgill, J.T., 1997. Use of heteroduplex analysis to classify Legionellae on the basis of $5 S$ rRNA gene sequences. J. Clin. Microbiol. 35, 16091611.

Robin, C., Desprez-Loustau, M.L., Capron, G., Delatour, C., 1998. First record of Phytophthora cinnamomi on cork and holm oak in France and evidence of pathogenicity. Ann. Sci. For. 55, 869-883.

Santini, A., Barzanti, G.P., Capretti, P., 2003. Susceptibility of some mesophilic hardwoods to alder Phytophthora. J. Phytopathol. 151, 406-410.

Spitzer, E.D., Lasker, B.A., Travis, S.J., Kobayashi, G.S., Medoff, G., 1989. Use of mitochondrial and ribosomal DNA polymorphisms to classify clinical and soil isolates of Histoplasma capsulatum. Infect. Immun. 57, 1409-1412.

Streito, J.-C., 2003. Phytophthora disease of alder: identification and distribution. In: Gibbs, J.N., Van Dijk, C., Webber, J.F. (Eds.), Phytophthora Disease of Alder in Europe. Forestry Commission Bulletin No. 126. HMSO, Edinburgh, pp. 25-38.

Swofford, D.L., 2002. PAUP. Phylogenetic Analysis Using Parsimony. Sinauer Associates,Sunderland, MA.

Thompson, J.D., Higgins, D.G., Gibson, T.J., 1994. CLUSTAL W: improving the sensitivity of progressive multiple sequence alignment through sequence weighting, positions-specific gap penalties and weight matrix choice. Nucleic Acids Res. 22, 4673-4680.

Whittaker, S.L., Assinder, S.J., Shaw, D.S., 1994. Inheritance of mitochondrial DNA in Phytophthora infestans. Mycol. Res. 98, 569-575. 